\title{
The Practice of Manumission through Negotiated Conditions in Imperial Rome
}

\author{
Egbert Koops
}

\subsection{INTRODUCTION}

Roman slaves often had to meet expressly negotiated conditions to obtain their freedom (\$14.2). The use of such conditions helps to explain why the Romans freed so many slaves $(\$ 14.3)$. They are an expression of the economic considerations that underlie the extraction and manumission model of Roman slavery (\$14.4). Agreements between masters and slaves occurred in practice and were recognized at law $(\$ 14.5)$. Conditions could be set among the living or by testament and could consist of settling accounts, money payments, or services in kind; some followed the slave and were actionable (\$14.6). The money to pay for freedom often came from the slave's patrimony or peculium (\$14.7). Although evidence is scarce, conditions and the corresponding manumission prices seem to have been of a type that could be met within years rather than decades (\$14.8). Extracting a price from slaves for their freedom lessened the future claims of patrons (\$14.9). For a certain type of slave, negotiated manumission conditions may have been the norm $(\$ 14.10)$. 


\subsection{TWO CASES: CRONION AND CALENUS}

In $\mathrm{AD} 142$, the cavalry trooper Antonius Silvanus drew up his will at his legion's winter camp at Alexandria. ${ }^{1}$ Silvanus instituted his son as heir, made out several legacies, and provided for the manumission of a slave: "I wish my slave Cronion to be free after my death if he has handled everything properly and transfers it to my aforementioned heir or agent, and I wish the manumission tax for him to be paid from my estate." 2 As a libertus orcinus, someone freed from beyond the grave, Cronion's obligations to his patron's son would have been quite limited. An orcinus was not required to provide labor or sustenance, or to show particular deference to his patron under classical Roman law (Loreti-Lorini 1925: 36-46; Champlin 1991: 139; Mouritsen 2011: 51), making him largely independent from his manumittor's family circle (Garnsey 1981: 362-3). ${ }^{3}$ In this case the heir was even burdened with the 5 percent manumission tax of the slave's market value (Liebs 2000: 126; Günther 2008: 118-24). ${ }^{4}$ So why was Cronion freed? Referring to the clause si recte tractaverit, "if he has handled everything properly," Wiedemann (1985: 164), recognizing that "manumission is a just reward for faithful service," argued that Silvanus wanted to fashion himself as a benign master. Yet the clause has a different and more legal meaning. Si recte tractaverit is a condition that should be read in conjunction with the obligation to transfer something (et tradiderit). The best explanation, it seems, is that Cronion had to account for and hand over the assets of the inheritance.

1 FIRA III 47. The will surfaced from the Egyptian sands in 1938 and remains the completest specimen of a Roman testament to date. Liebs 2000: 114-19.

2 FIRA III 47, lines 31-7: Cronionem / seruom meum pos $(t)$ mortem meam / si omnia recte tractaverit et / tra(di)derit heredi meo s(upra) s(cripto) uel / procuratori tunc liberum uolo / esse uicesima $<n>\{m\}$ que pro eo ex / bonis meis dari uolo.

${ }^{3}$ Justinian made extensive changes to the Roman law of patronage by his constitution of $\mathrm{AD} 531$, found in C. 6.4 .4 (partially restored from the Basilica and referred to in Inst. 3.7.3). The position of the orcinus was completely revised by C. 6.4.4.27 (preserved in the Veronese Codex). On the interpolation of other texts in consequence of this law, see Loreti-Lorini 1925: 47-60; Harada 1939a, 1939b. Further discussion in $\$ 14.9$.

4 A similar clause appears in line 53 of the so-called testament of 'Dasumius' ( $A E$ $2005,191)$, though the clause in lines $117-18$ refers to the vice $(n)$ sima hereditatis. For an example of manumission inter vivos with payment of the manumission tax by the master, see P.Tebt. II 407 (AD 199); for manumission testamento with payment by the heir, see P.Sijp. 44 (AD c.130). 
The legacies of 1,350 denarii total represent the value of two to six slaves, ${ }^{5}$ quite apart from the gift of freedom to Cronion. The inheritance will have been bigger still, totaling perhaps 4,000 denarii (Champlin 1991: 54, 184-6), and so the cavalry soldier Antonius Silvanus appears to have been a moderately wealthy man. Perhaps Cronion was a trusted slave who looked after Silvanus' accounts; or perhaps he had to render an accounting for the business he conducted out of his slave patrimony (peculium). Even though a slave had little legal personality and could technically hold no patrimony, his master could allow the use of certain assets as if they belonged to the slave, giving him a measure of autonomy and an incentive to increase his holdings (\$14.7). In any case, it is fairly common in legal sources to find slaves accounting for their administration to their masters' heirs in fulfillment of a condition for their release (Buckland 1908: 494-6). The Digest contains roughly seventy instances of a clause stipulating that a slave shall be free if he has rendered an accounting (si rationem dederit/reddidit), ${ }^{6}$ many of which are drawn from actual practice (Morabito 1981: 170-2).

In an example that follows the wording of Silvanus' will quite closely, probably also drawn from an actual testament, the jurist Pomponius cites the writings of the late Republican jurist Labeo: "my accountant Calenus is to be free and to have all his goods and a legacy of a hundred, if it appears that he has kept the accounts diligently" (si rationes diligenter tractasse). ${ }^{7}$ Pomponius goes on to explain that a diligence is required that profits the master rather than the slave, not only in calculating accounts but also in paying over the balance (reliqua). This second part is revealing. What Pomponius and Labeo have in mind is a case in which a slave receives his freedom together with his peculium, if he calculates and pays over in good faith the remainder of the accounts in his care. The slave-accountant

5 Compare the slave prices mentioned in Ruffing and Drexhage 2008: 321-36. The total comes to over four years' of legionary wages at 300 denarii a year, not including donatives (Liebs 2000: 121). Difficulties in comparing slave prices: Harper 2010: 212. Influence of exonerations and guarantees: Arzt-Grabner 2010: 30-1. Market integration: Temin 2001, 2004; Scheidel 2005b.

6 Similar clauses appear in lines 41 and 51 of the 'Dasumius' testament ( $A E$ 2005, 191).

7 D. 40.7.21 pr. (Pomp. 7 Plaut.; Lab., Post.): Calenus dispensator meus, si rationes diligenter tractasse videbitur, liber esto suaque omnia et centum habeto. The same case is referred to in D. 40.4.8 (Pomp. 5 Sab.). For similar cases, see D. 33.8.23.1 (Scaev. 15 dig.) and D. 40.7.40.3 (Scaev. 24 dig.). 
Calenus had personal money as well as access to his master's money, and inevitably the two would get mixed up. The less of reliqua there would be for the master, the more peculium there would be for Calenus: hence the need to explain that the slave's interest should not prevail. Elsewhere, Pomponius refers to a statement by the late first-century jurists Neratius and Aristo that a slave can give security for the unclear (obscurius) part of the balance. Otherwise hardly any slave would ever become free, "owing to the uncertainty of the account and this type of affair." Celsus, writing in the first half of the second century, allows a similar glimpse. If a slave has been freed on condition of providing an account, but the heir will not allow him to sell off his peculium to raise money to pay the balance, then the slave will be free as if the condition were fulfilled. ${ }^{9}$ The Roman jurists consider it near-normal that the accounts of master and slave become entangled. They also consider it acceptable that a slave supply from his personal money what went missing from his master's accounts. And they consider this sufficient to fulfill the condition for manumission. ${ }^{10}$ Africanus, from the middle of the second century, is clear on the point: "to give an accounting means no more than to pay the balance" and as long as this happens in good faith, the slave will be free. ${ }^{11}$

Set against the legal sources, Cronion's manumission appears in a different light than Wiedemann thought. "Faithful service" is not the condition for freedom, but Cronion's truthful accounting and handing over of the balance. Much like Calenus, Cronion had access to his master's accounts and by implication probably held a peculium. If so, it was not explicitly granted to him as a legacy and was therefore considered withdrawn in as far as anything would be left after settling the accounts. ${ }^{12}$ Seen in this light, his manumission appears less as an act of benevolence and more as the winding-up of a partnership.

${ }^{8}$ D. 40.7 .5 pr. (Pomp. 8 Sab.): incerta causa rationis et genere negotii huiusmodi.

9 D. 40.7.23.1 (Cels. 22 dig.). This follows from the legal principle that a condition is automatically met if someone who stands to gain from its non-fulfillment hinders or prevents its fulfillment (Kaser 1971: 257).

10 e.g. D. 40.5 .41 .7 and 9 (Scaev. 4 resp.); D. 40.7 .40 pr. (Scaev. 24 dig.).

11 D. 35.1 .32 (Afr. 9 quaest.): rationes reddere nihil aliud sit quam reliqua solvere. But also see D. 35.1 .82 (Call. 2 quaest.) for an additional obligation to surrender the books. Columella ( $R R$ 1.8.13) advises masters not to allow farm overseers to trade for their own profit at all, because it increases the difficulty of settling accounts.

12 Fr. Vat. 261 (Pap. 12 resp.); D. 33.8.8.7 (Ulp. 25 Sab.); C. 7.23.1 (Diocl./Max., AD 294); Inst. 2.20.20. 
The slave's help is indispensable to establish the contents of the inheritance, and manumission is a strong incentive to produce a truthful account. ${ }^{13}$ Of course Silvanus could have revoked Cronion's privileges and peculium at any time, or could have ordered him to render an accounting $(\$ 14.5) .{ }^{14}$ But death is a natural moment to extricate the affairs of master and trusted slave, precisely because the heirs lack sufficient information about the inheritance if the slave bookkeeper does not cooperate (Dari-Mattiacci 2013: 84-7). The legacies that are often coupled to this type of manumission, as in the case of the accountant Calenus, only reinforce this view. They put a premium on a truthful account, leading to manumission, while the penalty for a detected lie is continued slavery, thereby tipping the scales in favor of truth.

\subsection{THE FREQUENCY OF MANUMISSION}

It would be amiss to suggest that Cronion or the dispensator Calenus were typical Roman slaves. Not every employee in a modern firm has access to the board of directors or the corporate bank account and not every Roman slave had access to his master, let alone his master's accounts. Slaves occupied a spectrum of social positions (Finley 1985: 67-8; Alföldy 2011: 196). Even so, Cronion and Calenus represent a type that is frequently encountered in literary sources, that predominates in the epigraphy, and that receives most of the jurists' attention. Selection bias cannot be avoided, since too little is known about the vast bulk of undocumented Roman slaves, including almost all the agricultural slaves, to say whether, when, and how they were manumitted, or in what numbers. For this reason, most of what follows applies only to a certain class of privileged or skilled slaves (Fenoaltea 1984), or to those employed in positions of trust (Dari-Mattiacci

\footnotetext{
13 This is not to say that the account will necessarily be truthful. The slave may take the dangerous gamble that his fraud will go undetected, netting him both freedom and (more) money. D. 27.3.1.3 (Ulp. 36 Ed.); D. 40.4 .22 (Afr. 9 quaest.); D. 40.5 .23 pr. (Pap. 9 resp.); D. 40.5 .41 .11 (Scaev. 4 resp.); D. 40.7 .40 pr. (Scaev. 24 dig.).

${ }^{14}$ D. 33.8 .19 pr. (Pap. 7 resp.): "when a master wanted to manumit a slave, he ordered him to provide an inventory of his peculium, and thereby the slave received his freedom" (cum dominus servum vellet manumittere, professionem edi sibi peculii iussit atque ita servus libertatem accepit). Also see D. 18.1.7 pr. (Ulp. 28 Sab.).
} 
2013: 105-6), and not to Apuleius' slave millers or the Spanish miners mentioned by Diodorus Siculus, "who would rather be dead than alive." ${ }^{15}$ Certain claims can be made, however, with regard to this select group of documented Roman slaves.

One of these claims takes the form of a question famously posed by Keith Hopkins (1978: 115): "Why did the Romans free so many slaves?" The number of references to freed slaves is staggering indeed. Rare cases of mass manumission aside (Westermann 1955: 135-6; Hopkins 1978: 115), many active, prosperous, or high-ranking freedmen appear in literary sources (Garnsey 1981: 359-61) ${ }^{16}$ and the economy of Roman Italy has been rightfully characterized as a "freedmen economy" (Verboven 2012). Three-quarters of the funerary inscriptions in Rome concern former slaves and the proportion is high as well for other Italian cities (Mouritsen 2005: 38-9, Verboven 2012: 90-1). Of the more than 506,000 Latin inscriptions catalogued in the Clauss-Slaby online database, over 27,000 refer to liberti. Freedmen figure in more than 1,000 legal fragments and their position was subject to a constant stream of legislation. ${ }^{17}$ Unfortunately, although such figures provide the notion that freedmen were common enough to matter, they reveal little about their relative number. The interests of writers and their readership shape literary sources, ${ }^{18}$ inscriptions reflect the strong epigraphical habit of freedmen (Mouritsen 2005: 55-63), and not every legal text presents a case drawn from actual practice. Some support can be found in the importance literary sources accord the vice(n)sima manumissionis, the manumission tax, but no reliable figures can be drawn from it (Bradley 1987: 149-50; Günther 2008: 98-9), nor from the number of public grain recipients (Mouritsen 2011: 120-3). Be this as it may, few scholars would dispute that the Romans freed 'many' slaves.

Quantifying 'many' remains difficult, both in terms of the number of slaves at any given time and in terms of the ratio of slaves to free persons. Two figures are generally adduced: the census returns for

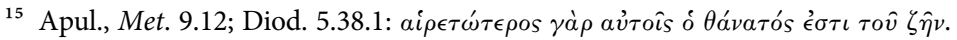

16 e.g. Cass. Dio 50.10.4-5 and 51.3.3; Cic., Balb. 24; Philo, Leg. ad Gai. 155; Tac., Ann. 13.27.

${ }^{17}$ Lopez Barja de Quiroga (1998: 161-3) provides a long list, only covering the Junian Latins.

${ }^{18}$ Even freedmen authors such as Epictetus, Phaedrus, and Terentius provide little information on the prospects of the slave population. On Phaedrus, see Bradley (1987: 150-3). On the anonymous Life of Aesop, see Hopkins (1993: 10-27).
} 
Roman Egypt, which show a ratio close to 11 percent (Bagnall and Frier 1994: 48), and Galen's cryptic reference to the roughly 20-30 percent slave population of Pergamum (Harris 1999: 65). ${ }^{19}$ It is difficult to proceed from these figures to an estimate for Roman Italy, let alone the rest of the Empire. As Scheidel (2005a: 64-6) has pointed out, the prevalent notion that slaves made up a third of the Roman population is nothing more than a shaky top-down guess. By stocking the Roman elite with a number of slaves according to their status, applying the data from Roman Egypt to the Italian cities, and extrapolating from the production levels and demand for a slave workforce in agriculture, Scheidel (2005a: 66-71) arrived at a bottom-up estimate of anywhere between 500,000-1,000,000 urban slaves and 250,000-750,000 rural slaves for Roman Italy. Depending on the size of the free population, a figure which is also problematic, slaves may have made up between 13-28 percent of the Italian population if one assumes the 'low count' for the total population (Scheidel 2008: 19-30). Such a margin of uncertainty precludes quantitative claims about the percentage of slaves manumitted, particularly since the weight of various sources in the slave supply is still heavily debated (Harris 1980; Scheidel 1997; Harris 1999; Scheidel 2005a). Because births seem to have been a major source of new slaves, female manumission rates cannot have been overly high at child-bearing age or the slave population would plummet, which is not supported by other evidence. But the incidence of male manumission and late-life female manumission has less of a demographic effect and may have been high. ${ }^{20}$ Scheidel (1997: 160-6, 2005: 76) has employed a purely hypothetical model of 10-20 percent per five-year age cohort, starting at age 25 , which means roughly half to threequarters of the slave population would have been released by age 50 . This hypothetical model has met with general silent acceptance (Verboven 2012: 92), which means no better guess is currently available.

In a seminal study of the age at death given in over 1,800 funerary inscriptions, Alföldy (1972: 346-54) has shown that a large majority of the epigraphically commemorated ex-slaves had been released

19 Gal., Propr. an. 9.13 (Corpus medicorum Graecorum V 4.1.1).

${ }^{20}$ Manumission was also used as an incentive for childbirth. Colum., RR 1.8.19; Fr. de iure fisci 13; D. 1.5.15 (Tryph. 10 disp.); D. 40.7.3.16 (Ulp. 27 Sab.). 
before the age of 30, or at most between 30 and $40 .{ }^{21}$ The age of 30 was not chosen randomly: it was the legal age for manumission leading to Roman citizenship under the Augustan lex Aelia Sentia of AD $4 .^{22}$ Alföldy claimed that manumission shortly after 30 constituted the "Normalfall" with which every slave could reckon. This assertion met with severe criticism (Hopkins 1978: 127; Garnsey 1981: 361-3; Wiedemann 1985: 162-3). It was argued that slaves were only commemorated at an early age; that only trusted slaves were commemorated at all; and that epigraphically commemorated freedmen form an atypical group of "successful" ex-slaves by their very nature. In addition, Alföldy's figure could not generally apply to female slaves, or the slave population would never come close to reproducing itself (Scheidel 1997: 165-6). Yet the simple fact remains that the majority of epigraphically commemorated (ex-)slaves were manumitted early, when a reasonable part of their productive lives still lay ahead. True enough, the epigraphical data cannot be used as a demographic sample (Mouritsen 2011: 132-6), but it does show that for a certain class of slaves, early manumission was the norm.

Employing similar methods as Alföldy with a non-overlapping data set, Weaver (1972: 97-104) concluded that manumission between the ages of 30 and 40 was normal for imperial slaves (familia Caesaris). A different, more random sample is offered by the census returns from Roman Egypt. ${ }^{23}$ Bagnall and Frier (1994: 71, 94, 156-8, 342-3) indicate that male slaves in Roman Egypt were generally freed between ages 30 and 40, though women were as a rule not manumitted while they could still bear children. A similar trend appears in Romano-Egyptian documents that provide the age of slaves or freedmen (Wiedemann 1985: 163). Finally, a Greek census inscription from the late fourth century lists 152 named slaves and 87 ages on a single agricultural estate on the island of Thera (Harper 2008: 106-16). Males may be under-reported for tax reasons, but even so the same pattern emerges as from the Romano-Egyptian data, that is to say a high level of probable male manumission after 30. Perhaps it

\footnotetext{
21 As much as 67 percent in Rome itself, though regional differences should be kept in mind. As Alföldy notes, this percentage even understates the case, as freedmen who died at a later age may have been released earlier.

22 Gai., Inst. 1.18; Ulp., Epit. 1.12.

23 The point can always be made that the published census returns for Roman Egypt cover three centuries, only mention 118 slaves, and may reflect local circumstances such as a lesser demand for slave labor.
} 
is a localized and fairly late snapshot. But at some point the question becomes how many "special cases" it takes to establish a general case, particularly since no study has provided any evidence to the contrary. ${ }^{24}$ The incidence of male and female manumission varies remarkably between sources, ${ }^{25}$ but for men, at least, manumission between the ages of 30 and 40 appears to have been frequent. The jurists suggest that the requirements for formal manumission were interpreted very leniently after 30 , and quite strictly beforehand. ${ }^{26}$ Even so, it goes without saying that some slaves were never freed.

\subsection{ECONOMIC CONSIDERATIONS FOR MANUMISSION}

All slaves were expensive, both measured against wheat equivalent and against daily wages (Scheidel 2005b; Ruffing and Drexhage 2008: 341-7), and outside of the elite most households will have owned only a few (Bagnall and Frier 1994: 48-9), either as a status symbol and for domestic work, or to work beside their owner and provide income in the "family economy" (Groen-Vallinga 2017: 98-9). Slaves needed sustenance $^{27}$ and slave children at least had little earning power (Morabito 1981: 64-5) ${ }^{28}$ Some were taught trades or skills at considerable

${ }^{24}$ The over 1,200 Delphic manumission records from the second century BC through the first century AD do not provide firm age indications (Hopkins 1978: 133-71). The same is true of the epitaphs of the urban slaves and freedmen of the elite Roman households (Treggiari 1975a: 58, 1975b: 395-400).

${ }^{25}$ Alföldy (1972: 351) noted a higher incidence of female than male manumission before 30 in the funerary inscriptions. The census returns from Roman Egypt and the Thera inscription show quite the opposite pattern, which is probably closer to reality. The difference may be due to the practice of releasing and then marrying young slave women (Wacke 2001), who stood a much better chance of being commemorated.

${ }^{26}$ Gai., Inst. 1.20: maiores vero triginta annorum servi semper manumitti solent, "slaves over 30 are wont to be manumitted at any time." Also see D. 40.2.7 (Gai. 1 cott.); D. 40.2 .8 (Ulp. 5 Ed.).

${ }^{27}$ Juvenal and Seneca complain of the cost (Sat. 3.166-67; Tranq. 8.8). A wet nurse for an infant slave foundling cost 10 drachmae and half a liter of oil per month $(B G U$ IV 1107, $13 \mathrm{BC}$ ); a slave wet nurse for a free infant cost 400 drachmae for two years (P. Oxy. I 91, AD 187).

${ }^{28}$ e.g. a legacy of the use of a slave child only takes effect after infancy, and no value is placed on his labor until the age of five: D. 7.1 .55 (Pomp. 26 Q. Muc.); D. 7.7.6,1 (Ulp. 55 Ed.). 
cost (Verboven 2012: 94) ${ }^{29}$ Even the residual value of slaves was high. Petronius has a freedman claim that he paid 1,000 denarii for his freedom after forty years of slavery. ${ }^{30}$ The highest actual age that can be related to a specific price is in the manumission certificate of Antonius Hermes, aged 40, for whom 20 denarii in taxes were paid, putting his value at a minimum of 400 denarii. ${ }^{31}$ To release any slave meant a sacrifice both in status and earning capacity for most households, not to mention the difficulty of recouping the investment under a system of early manumission. So why were they freed in such numbers? As Hopkins noted (1978: 117), "Roman society was not marked by altruism."

Of course, some manumissions were prompted by non-pecuniary considerations. Slaves and masters lived in close proximity and relationships were doubtlessly formed. Some slaves were released in recognition of their accomplishments ${ }^{32}$ or in gratitude for exceptional service, ${ }^{33}$ and to a large extent such practice represents the literary ideal (Wiedemann 1985: 163-5; Mouritsen 2011: 30-5). ${ }^{34}$ Slave girls

29 P. Oxy. IV $724=$ Chr. 140 (apprenticeship to stenographer, 120 drachmae, AD 155); but compare P. Oxy. XIV 1647 (AD c.185, paid apprenticeship to weaver, wages rising from 8 drachmae per month in the first year to 20 drachmae per month in the fourth year, with eighteen days off per year). Value added by training: Plut., Cat. 21.7; Cic., Q. Rosc. 10; Hor., Ep. 2.2.5-8; Mart. 10.62. Also see the famous case reported by Paulus, D. 19.1 .43 (5 quaest.). Conversely, Habinnas counts himself lucky that he spent no money to teach what his slave could also pick up on the streets (Petr., Sat. 68.7).

30 Petr., Sat. 57.6 and 57.9.

31 FIRA III 10bis (Egypt, second century). The true price may have been higher still because of tax evasion. If both examples are explained away as cases of self-purchase (which is not evident in the case of Antonius Hermes), the next highest age is a slave woman aged 30-39 who sold for 200-25 denarii (800-900 drachmae, P. Mich. XV 707, after AD 185, damaged); or a male slave aged 32 who sold for 225 denarii ( 900 drachmae, P. Oxy. XXXVIII 2856, AD 91/92). In P. Hamb. I 63 (AD 125/126) two prisoners of war, one aged 38 and the other's age not given, are sold for a combined price of 350 denarii (1,400 drachmae).

32 e.g. after offering money the grammarian Lenaeus was freed gratis by Pompey in recognition of his learning (Suet., Gramm. 15), and when Cicero freed his secretary Tiro in 53 вс, his brother Quintus famously wrote that Tiro would rather be their friend than their slave (Cic., Fam. 16.16.1).

${ }^{33}$ Fending off robbers, uncovering a plot, defending or healing their master, etc.: D. 40.2.15.1 (Paul. 1 Ael. Sent.). Denouncing the murder of their master: Sc. Silanianum, D. 29.5 rubr. (Buckland 1908: 600-2). The grant of freedom for informing against a criminal master to the benefit of the state seems to be a later development (Buckland 1908: 598-9); but see App., Bell. civ. 4.11 for special circumstances (proscriptions).

${ }^{34}$ Dion. Hal., Ant. Rom. 4.24.4. 
were bought and set free at an early age for the purpose of marriage, which brought material benefit to their masters under the Augustan matrimony laws (Wacke 2001). The lex Aelia Sentia contained an exception for next of kin and future wives, who could be formally manumitted and acquire Roman citizenship before the prescribed age of $30 . .^{35}$ If a union with a slave girl proved fruitful, the resulting children might be freed as well, though the relation between a master and his natural slave children should not be sentimentalized by assuming this as a necessary outcome. ${ }^{36}$ Dying slaves were sometimes manumitted. The practice had little value in the eyes of a jurist and was the butt of one of Petronius' jokes, since the bereaved master still owed manumission taxes (Kleijwegt 2002). ${ }^{37}$ Sometimes, dying slaves were simply abandoned and left to fend for themselves. ${ }^{38}$ Slave abandonment may either have been a common practice or, under the emperor Claudius, an outrageous but isolated incident that sparked imperial intervention. The same is true for the manumission of actors or gladiators following popular acclaim, which was criticized or forbidden by several emperors. ${ }^{39}$ Equally frowned upon was the large-scale manumission to gain clients or fill out funeral processions, which Dionysius of Halicarnassus claims to have witnessed. ${ }^{40}$ Such cases seem rare (Champlin 1991: 141). Finally, a slave could be forced to take up a debt-ridden inheritance as a necessary heir (heres necessarius), a quaint institution that merited considerable legal attention because a necessary heir was often included in the order of succession

${ }^{35}$ Gai., Inst. 1.19; D. 40.2 .11 (Ulp. 6 procons.); D. 40.2 .12 (Ulp. 2 Ael. Sent.); D. 40.2 .13 (Ulp. 6 procons.); D. 40.2.20.2-3 (Ulp. 2 off. cons.). The slave's age requirement was abolished by Justinian (C. 7.15.2, AD 530).

36 Some testaments provide for the manumission of likely slave children, which implies that the master and father had no intention of manumitting immediately: FIRA III $50=$ Chr. 316 (will of C. Longinus Castor, AD 194); FIRA III 10 (Dameis aged 13 freed with peculium and liberated from patronage, third century).

37 D. 40.4 .17 pr. (Iul. 42 dig.); Petr., Sat. 65.10. For deathbed manumission, see Mart. 1.101; Pliny, Ep. 8.16; CIL VI 9317; CIL X 2381 = ILS 7842; SB XXII 15345.

${ }^{38}$ Claudius decreed that abandoned slaves need not return to their masters if they recovered, but were free with the status of Junian Latins, giving them at least some recognition: Suet., Claud. 25.2; Cass. Dio 60.29.7; D. 40.8.2 (Mod. 6 reg.); C. 7.6.1.3 (Just., AD 531).

39 Tiberius: Cass. Dio 57.11.6; Suet., Tib. 47; Hadrian: Cass. Dio 69.16.3; Marcus Aurelius: D. 40.9 .17 pr. (Paul. 3 Ael. Sent.); C. 7.11 .3 (Alex., AD 223-4); Cass. Dio 72.29 .

${ }^{40}$ Dion. Hal., Ant. Rom. 4.24.8. Also see Pers., Sat. 3.105-6; Petr., Sat. 42.6. 
to ensure that the inheritance was taken (Buckland 1908: 505-12). ${ }^{41}$ Again, the number of cases in which this failsafe was activated and the slave was freed may have been limited (Champlin 1991: 137).

The problem with such manumission motives is that blood ties, faithful service, deathbed grants, abandonment, popular success in the arena or on stage, debt-ridden inheritances, etc. can hardly account for systematic male manumission at an early age. It is difficult to reconcile that manumission was "both very common and very selective," as Mouritsen claims (2011: 140), who admits that it was "essentially a financial transaction" (2011: 146) while simultaneously downplaying economic considerations (2011: 159-80). Instead of the fanciful notion of "common selection," the best explanation why the Romans freed so many slaves remains the one offered by Hopkins (1978: 118) and Alföldy (1972: 360-3): slaves paid considerable sums of money for their freedom. The Roman slave system exploited the desire for freedom to great effect, offering manumission as an incentive for the ideal type of hardworking and frugal slave who would merit freedom (Hopkins 1978: $128,147-8)$. This meant that extraction of the full value of a slave's labor was postponed for some time. Even so, giving slaves a stake in their productivity by allowing them to save part of their earnings ensured cooperation and harder work at lower supervision costs (see already Cohen 1951: 222). ${ }^{42}$ The risk of undisclosed funds following the slave into freedom was partially countered by giving patrons a legally protected stake in any future earnings of a freedman, through an expectancy to inherit $(\$ 14.9)$ as his closest agnatic kin (Kaser 1971: 697; Gardner 1993: 19-20). ${ }^{43}$ Thus, slavery and manumission were marked by a stepped extraction process. First, labor was extracted for which the slave received less than full compensation; then a manumission price would be paid, enabling the master to reinvest while obtaining a freedman; and upon the freedman's death, the patron would often take part of the inheritance.

\footnotetext{
${ }^{41}$ Gai., Inst. 2.153; Ulp., Epit. 1.14. See line 13 of the testament of 'Dasumius' ( $A E$ 2005, 191).

${ }^{42}$ Varro, $R R$ 1.17.5-7 and 1.19.3. But note the quite different opinion of Colum., $R R$ 1.8.13 and 11.1.24. Aristotle hints at the problem as well (Oecon. 1.1344b).

${ }^{43}$ Gai., Inst. 3.39 and following. Gaius dedicates a full thirty-eight paragraphs to the convoluted law of freedman inheritance.
} 
The mechanism described here was not invented by Augustus. Statuliberi, slaves freed by testament on condition of payment of a sum of money, already appear in the Law of the Twelve Tables. ${ }^{44}$ But the Augustan manumission laws surely fostered this form of manumission to serve state interests. ${ }^{45}$ On the one hand, a high manumission rate was desirable as it meant that enough freedmen were visible and successful for manumission to present a believable scenario, fostering obedience on the part of the slave population (Bradley 1994: 163). ${ }^{46}$ Moreover, freed slaves were taken into the citizen body, adding new citizens in a practice that some considered an important contribution to the Roman success. ${ }^{47}$ On the other hand, Augustus aimed to add only the "best" slaves as citizens, ${ }^{48}$ that is to say those who deserved freedom in the eye of a discerning master by their frugality or other virtues. These conflicting aims were both addressed by the lex Iunia (Norbana) of $17 \mathrm{BC},{ }^{49}$ which created a waiting room class of second-rate free persons, consisting of freedmen who had been granted their liberty through informal manumission and lacked full citizenship in consequence. ${ }^{50}$ Such Junian Latins do not stand out in the epigraphy (Weaver 1990) and are difficult to track in other sources. ${ }^{51}$ With some justice Weaver (1997: 55) has called this status group "a black hole of large but unknown

44 Tab. VII,12 (Bruns) = Tab. VI.2 (Flach): Ulp., Epit. 2.4; D. 40.7.25 (Mod. 9 diff.); D. 40.7.29.1 (Pomp. 18 Q. Muc.). Also see Fest., s.v. statu liber.

${ }^{45}$ Augustus' program included the lex Iunia (17 BC), lex Fufia Caninia (2 BC), lex Aelia Sentia (AD 4) and the lex Papia Poppaea (AD 9). With minor modifications these laws were in place for over five hundred years, until most were abolished by Justinian.

${ }^{46}$ Hinted at by Dion. Hal., Ant. Rom. 4.24.7, perhaps in response to the slave revolts of the late Republic.

${ }^{47}$ Cf. the famous (but slightly erroneous) letter of Philip V of Macedon to the city of Larissa, $S I G^{3} 543=I L S 8763$ (214 BC). Also see Cass. Dio 56.7.6.

${ }^{48}$ Cass. Dio 56.33.1-3 (but perhaps mistaken, see Suet., Aug. 101); Suet., Aug. 40.3-4.

49 The date is in dispute (the other possibility being AD 19, under Tiberius), but since the status group is named after the Junian law, it seems likely this law preceded the lex Aelia Sentia that also regulated their position. Buckland 1908: 534-7; Sirks 1981: 250-1; Weaver 1997: 58-60; Lopez Barja de Quiroga 1998: 137-8.

${ }^{50}$ That is to say not by iusta manumissio in front of a magistrate or by testament, but by the mere will of their master. Gai., Inst. 1.17 and 3.56; Fr. Dos. 4-5; Quint., Decl. min. 340 and 342. Of course proof was essential: see Mart. 9.87 and the unsavory tale in Cic., Att. 7.2.8.

${ }^{51}$ Isolated cases: Suet., Vesp. 3.1 (later declared freeborn); Plin., Ep. 7.16.4 (offer of magistrate's assistance); Plin., Ep. 10.5.2, 10.11.2 and 10.104 (requests for citizenship grants); Mart. 1.101 (deathbed manumission); $A E$ 1959, 297 (probatio anniculi). See now Emmerson (2011). 
proportions." 52 It seems likely that informal manumission was frequently employed. Patrons of Junian Latins retained a claim to their entire inheritance, which would fall to them as if the deceased freedman had remained a slave. ${ }^{53}$ This gave Junian Latins a strong incentive to obtain full Roman citizenship by a second, formal manumission (iteratio, Buckland 1908: 714-18; Sirks 1983). The requirement of further cooperation from the patron for formal manumission ensured continued dependence and further opportunities for extraction. ${ }^{54}$ In any case, the overall effect of the Augustan laws was that informally manumitting slaves as Junian Latins was relatively easy, maintaining a high manumission rate, while formally turning slaves into Roman citizens was more difficult, but not impossible, maintaining the desirability of citizenship. From a systematic point of view, manumission reinforced slavery (Hopkins 1978: 118).

\subsection{IMPLICATIONS OF FREEDOM PURCHASE: AGREEMENTS AND TERMS}

The extraction process described here has two implications. The first is that manumission was often the outcome of negotiations between master and slave. This may be a difficult proposition, considering the power disparity, but there is enough evidence to believe agreements or promises occurred frequently. In the Roman view, slaves were capable of forming relations governed by bona fides or good faith (Horsmann 1986: 317), which in turn meant that to break one's word, even against a slave, was to act against good morals (Kaser 1971: 200). Pliny allowed slaves to bequeath part of "their" property, as long as they made it over within the household, and Columella advised to offer exemption from work to slave women who bore more than two

\footnotetext{
52 As a status group, Junian Latins survived the mass grant of Roman citizenship by the Constitutio Antoniniana of AD 212, and the status was only abolished by Justinian (C. 7.6.1.12-12a, AD 531). Koops 2012.

${ }^{53}$ Gnomon 19 = BGU 1210; Gai., Inst. 3.56; Inst. 3.7.4; C. 7.6.1.1b (Just., AD 531).

54 Fr. Dos. 14; Gai., Inst. 1.35; Fr. Vat. 221; Ulp., Epit. 3.4. Also see Tac., Ann. 13.27. The state tapped this source of income as well, as successive emperors granted citizenship in return for any number of expensive civic services. Gai., Inst. 1.32c-34; Ulp., Epit. 3.6.
} 
children, and freedom to those who bore more than three. ${ }^{55}$ The novelist Achilles Tatius describes a scene in which the slave girl Lakaina negotiates with Melite for her purchase for 2,000 drachmae from an abusive master, offering to repay as soon as possible. ${ }^{56}$ In an inscription at the Rijksmuseum of Oudheden at Leiden, a certain Ericthonius is mentioned, "who died age 28, when he ought to be manumitted at age 30." ${ }^{\prime 2}$ The use of the verb debere may imply a social norm, but also an agreement between a master and his slave or a third party concerning the term of servitude; in any case Ericthonius' master was felt to be morally or legally required to free him at age $30 .^{58}$ Manumission agreements, pactiones pro libertate, are common in legal sources. As early as the first century BC, Alfenus discusses a case in which a slave has contracted with his master to purchase his freedom; when the master dies, the slave has not yet paid the full amount but is freed by testament. ${ }^{59}$ Whether he can reclaim what he has already paid depends on whether the master entered the payment into his own accounts, or kept it apart as belonging to the slave's peculium. The implication that legal obligations could arise between masters and slaves as debtors and creditors is borne out by a multitude of texts (Buckland 1908: 220-5; Morabito 1981: 105-10). As Ulpian notes, slaves were bound and could bind others naturaliter by their contracts. ${ }^{60}$

True, a master was under no legally enforceable obligation and merely under a moral obligation to uphold agreements made with his slaves. Masters might withdraw the peculium (Johnston 2002: $11-12),{ }^{61}$ sell the slave or assign him to a different station, or renege on their promise of manumission (Buckland 1908: 205, 640-3).

${ }^{55}$ Plin., Ep. 8.16.1-2 (note the inversion in Petr., Sat. 53.8, where Trimalchio is disinherited by his slaves); Colum., $R R$ 1.8.19. In the same letter, Pliny suggests that he manumits immaturos easily, that is those under 30 .

56 Ach. Tat. 5.17.

57 RMO Leiden (unpublished, EDCS-58700011): Dis manibus/Ericthonio animae/ sanctissimae · hic/cum deberet ann(is) XXX/manumitti - ann(os) XXIIX/decessit/ C(aius) Cilnius . Philetus/filio carissimo/fec(it) (Smyrna, second to third century). Compare CIL X 4917.

58 Especially in cases of self-sale into slavery, such agreements will have been common. Morabito 1981: 70-4; Harris 1999: 73-4. For discussion of the clause ut manumittatur, see 14.6 .

59 D. 40.1 .6 (Alf. 4 dig.). Also see D. 33.8.8.5 (Ulp. 25 Sab., referring to Labeo).

60 D. 44.7 .14 (Ulp. 7 disp.). Also see D. 12.6 .13 pr. (Paul. 10 Sab.); D. 12.6.64 (Tryph. 7 disp.).

${ }^{61}$ D. 15.1.7.6 (Ulp. 29 Ed.); D. 15.1.8 (Paul. 4 Sab.). Compare Plaut., Aul. 820-32. 
A rescript from Diocletian states that a mistress who agreed that her slave would be free after a certain period of servitude was not required to uphold the bargain; but even so, a different rescript from the same emperor states that a master who has received a slave's payment should at least be urged by the provincial governor to keep his promise of manumission. ${ }^{62}$ The ability to renege raises the question whether some masters would freeload on a social structure in which many kept their word (Watson 1987: 65, Kleijwegt 2012: 113-15). After the murder of the urban prefect Pedanius Secundus by his slave in $\mathrm{AD} 61$, the senate debated whether to apply the law that all slaves under the same roof were to be killed. Tacitus notes that the murderer was spurred to violence either "because he had been refused the freedom for which he had paid the price" or out of a lover's jealousy; but later, in the speech he attributes to the jurist Gaius Cassius Longinus, it is stated that the unnamed slave was avenging wrongs "because he had bargained with paternal money or because an ancestral slave was taken away"; this suggests that Tacitus rather believed a failed manumission deal to be the cause of violence. ${ }^{63}$ Roman masters were well aware of this potential threat: "as many enemies as slaves," as the proverb went. ${ }^{64}$ Not to keep one's word on matters as important as manumission could be dangerous in a society with a propensity toward violence (Morabito 1981: 135). Considerable legal ingenuity was expended on ways to neutralize this social danger by making the master's obligation to manumit enforceable at law. Examples are the use of a trusted third party or the allowance of certain claims against the master if an agreement had been confirmed by testament $(\$ 14.6)$. Such devices are far more common in the legal sources than simple pactiones between master and slave.

The second implication of agreements to purchase freedom would appear to be that Roman slaves were manumitted more often inter vivos, during the lifetime of their masters, than by testament. This runs counter to a tradition going back to Buckland (1908: 546), that testamentary manumission was more common by far because it guaranteed the use of the slave until death (Duff 1928: 25; Garnsey

${ }^{62}$ C. 7.16 .36 (Diocl./Max., AD 294); C. 4.6 .9 (Diocl./Max., AD 294). Also see C. 7.16.20 (Diocl./Max., AD 293).

${ }^{63}$ Tac., Ann. 14.42: seu negata libertate, cui pretium pepigerat, sive amore exoleti incensus et dominum aemulum non tolerans; Tac., Ann. 14.43: quia de paterna pecunia transegerat aut avitum mancipium detrahebatur.

${ }^{64}$ Sen., Ep. 47.5; Fest. s.v. quot servi (314L); Macr., Sat. 1.11.13. Also see Curt. 7.8.28. 
1981: 362; Patterson 1982: 223-4). ${ }^{65}$ Recently, scholarly opinion has swung the other way, claiming that manumission inter vivos represents the standard (Roth 2010: 98-9; Mouritsen 2011:180-3). In truth, there is little evidence for either claim. Testamentary manumission is referenced four times more often in the Digest (Morabito 1981: 166), but that may be due to the greater complexity of testaments and legacies, giving the lawyers and Byzantine lawmakers cause for attention. In literary and epigraphic sources both are encountered in roughly equal proportion, but accidents of preservation forbid any conclusion. Little importance can be attached to the rule that the slave peculium was considered granted unless withheld for manumission inter vivos, and was considered revoked unless granted for testamentary manumission. As Roth notes (2010: 95-104), because slaves paid for freedom out of their peculia, it would have been the subject of negotiation on the one hand, while on the other hand an implicit grant was often construed, for instance in cases of testamentary manumission on condition of payment of a certain sum.

Since it touches on slave expectations as well as manumission motives and numbers, ${ }^{66}$ it would seem important whether manumission inter vivos or by testament was more common. However, once one accepts the existence of a social practice of manumission payments, this opposition loses its relevance. A master would negotiate with a certain class of slaves and set certain terms. If the terms were met during his lifetime, he would usually free the slave; but it made sense to enshrine the terms in a testament or codicil as well, leading to a legally recognized position of the slave as a statuliber in case the master died before freeing his slave. Testamentary manumission put the agreement between master and slave on a securer footing for the slave: not because he expected to be released only at his master's death, but because he knew that the bargain would hold even if his master died. The heirs were not bound by any agreements between the deceased and his slave, but they were bound by the testator's will. A testament such as that of Silvanus $(\$ 14.2)$ cannot discount the possibility that Cronion may have been manumitted before the will came into effect; but if Cronion was still a slave when Silvanus died,

\footnotetext{
65 The self-purchase model vitiates this argument since it allows for the purchase of a replacement slave and the addition of a freedman.

${ }^{66}$ Because of the lex Fufia Caninia of 2 BC, which limited the number of slaves who could be freed by testament: Gai., Inst. 1.42; Ulp., Epit. 1.24; Paul., Sent. 4.14.4.
} 
his position as a statuliber would have been unassailable, not only by the heirs but also by any new owner to whom the heirs might sell him. Such conditions followed the slave (Buckland 1908: 286-7). Of course, slaves were powerless to prevent the testament from being modified by the testator during his lifetime, ${ }^{67}$ which happened frequently (Champlin 1991: 64-70); but that was no different than their position regarding any other agreement with their master. Moreover, there are traces of a practice of reading wills in public, asserting the social order of the household (Champlin 1991: 23-4) by communicating what lay in wait. ${ }^{68}$

Seen in this light, the important question is not how the Romans freed so many slaves-by testament or inter vivos - but under which terms. A testament is merely a way to enshrine a negotiated agreement and make it actionable. Over 90 percent of the fragments in the Digest dealing with manumission place a condition on attaining liberty (Morabito 1981: 174). The condition may consist of an amount to be paid, at once or over time, or of years of servitude, but it may also take the form of future service as a freedman; and it may be set by agreement or by testament, either directly or through an intermediary. The possibilities are endless (Champlin 1991: 139-40). And though their frequent occurrence should be taken with a grain of salt, since conditions give rise to greater legal problems than gratis manumission, it does show that manumission terms were at the forefront of jurists' minds (Table 14.1). Put differently,

\begin{tabular}{lc}
$\begin{array}{l}\text { Table 14.1. Manumission terms in the Digest } \\
\text { (\# of fragments). }\end{array}$ \\
\hline payment of price & 190 \\
\hline - price set inter vivos & $(71)$ \\
- price set by testament & $(119)$ \\
render accounting & 66 \\
fixed term or fixed age & 87 \\
imposition of operae & 101 \\
no condition (testament) & 31 \\
no condition (inter vivos) & 14 \\
\hline
\end{tabular}

${ }^{67}$ If (part of) a testament containing a manumission clause was suppressed, the slave could sue the heirs under a rescript from Marcus Aurelius and Commodus: D. 5.1 .53 (Herm. 1 epit.); D. 48.10 .7 (Marc. 2 Inst.).

${ }^{68}$ Petr., Sat. 71.1-3. 
such extensive discussion only makes sense if the purchase of manumission was common, and freedom had its price.

\subsection{FREEDOM PURCHASE AGREEMENTS AND THEIR ENFORCEABILITY}

Many slave systems in antiquity developed mechanisms whereby slaves purchased their freedom (Patterson 1982: 282-4). The best example is provided by the $1,200+$ inscriptions from Delphi (Hopkins 1978: 133-71), though manumission payments are encountered throughout the Hellenistic world (Zelnick-Abramovitz 2005: 207-47). Even so, a similar Roman practice is harder to substantiate outside of the legal texts. Few inscriptions mention whether a freedman paid for his liberty or received it gratis. ${ }^{69}$ Even when family relationships make paid-for manumission unlikely, a gift is hardly ever mentioned, which warrants the assumption that the reason for manumission was simply not considered worth inscribing. Unlike Greek manumission inscriptions, which were publicized on durable temple walls, Roman deeds and state records were kept on perishable materials. Freedom purchase appears quite often in the far better preserved documentary evidence from Roman Egypt (Scholl 2001), ${ }^{70}$ but no conclusions can be drawn about its prevalence, save that informal manumission is more common than the iusta manumissio leading to Roman citizenship. Literary sources provide more references to the purchase of freedom, starting as early as Plautus (d. 184 BC). When the slaves Stichus and Sagarinus encounter the courtesan Stephanium, they exclaim that "the peculium is wafted away, it is done; liberty has fled this slave."71 Many Plautine slaves have a peculium. It may be sizable through thrift or for comic effect, or merely limited to some livestock, but the Plautine slaves generally

${ }^{69}$ CIL XI $5400=$ ILS 7812 (doctor, 50,000 sesterces); CIL XII 5026 ([e]t pretio [obtin]uit, quod prec[e]/non valuit); CIL VI 2211 = FIRA III 80g (free); CIL VI 20905 (free, but curse tablet). CIL $\mathrm{II}^{2} 7.432$ can be read either way.

${ }^{70}$ e.g. P. Oxy. IV $202=$ Chr. 361 (per epistulam); FIRA III $11=$ Chr. 362; P. Lips. II 151; P. Oxy. IX 1205; (inter amicos); P. Oxy. IV 722 = Chr. 358; P. Turn. 19 (in front of agoranomoi); P. Flor. I 4 = Chr. 206; P. Oxy. XLIII 3117 (registration through court).

${ }_{71}$ Plaut., Stich. 751: [Stich.] Vapulat peculium, actum est. [Sag.] Fugit hoc libertas caput. 
attempt to buy their liberty or that of loved ones once they acquire some money. ${ }^{72}$ Other authors assume that slaves will work hard and save, or rob and swindle, even cheat their own bellies to find the necessary funds. ${ }^{73}$ The promise of freedom is considered an effective incentive for better work, ${ }^{74}$ and although literary authors can conceive of slaves who prefer sheltered servitude to insecure life on their own, ${ }^{75}$ such cases must have been rare in practice, considering the grave disadvantages of "social death" (Patterson 1982: 86-94; Hopkins 1993: 14). Martial refers to the advantages of "mastering" oneself $^{76}$ and Trimalchio's conlibertus Hermeros, who bought his freedom for the high price of 1,000 denarii after forty years of servitude (\$14.4), also claims to have purchased the freedom of his slave partner (contubernalis) to save her from groping hands. ${ }^{77}$ "Liberty is favored above all things," according to Gaius, ${ }^{78}$ and though the worth of freedom cannot be measured, its value can be priced. Skilled slaves may have cost a fantastic sum in the past, Pliny the Elder notes, but if that figure is topped in the present, it is because these slaves are purchasing their freedom. ${ }^{79}$ And when Vespasian became emperor, his old herdsman complained that the fox had changed his fur, but not his nature, so that he still needed to pay for manumission; conversely, Virgil's old shepherd Tityrus never had a hope of freedom and hence never a thought of saving. ${ }^{80}$

The purchase of freedom is ubiquitous in legal sources. In the Digest alone, close to two hundred fragments deal with the complications arising from its various legal forms. Aside from simple pactiones and the more elaborate obligation to render an accounting

\footnotetext{
72 Plaut., Asin. 497-8 (frugality); Plaut., Asin. 539-40 (flock); Plaut., Trinum. 727-8 (talent in the bank); Plaut., Trinum. 433-4 (peculium generally assumed). Purchase of freedom is mentioned inter alia in Plaut., Asin. 650-2 and 673; Aul. 309-10; Most. 300; Pers. 34-8; Rud. 1408-10.

${ }^{73}$ Cic., Par. stoic. 5.39; Sen., Ep. 80.4; Pers., Sat. 5.73-99 and 5.174-5. Also see Ter. Phor. 1.35-46 (saving); Dion. Hal., Ant. Rom. 4.24 .4 (saving, theft); Plin., NH 33.6.26 (theft of food); Apul., Met. 10.14 (theft of food); Juv., Sat. 3.188-9 (bribes).

${ }^{74}$ Cic., Rab. Perd. 15. Also see Sen., Ep. 80.4.

75 Plaut., Capt. 119-20 and 270-3; Epict. 4.1.33-5; Mart. 9.92. $\quad 76$ Mart. 2.68.

77 Petr., Sat. 57.6: "I have purchased the freedom of my slave bedmate, so that no one might wipe his hands in her hair" (contubernalem meam redemi, ne quis in $<$ capillis $>$ illius manus tergeret).

${ }^{78}$ D. 50.17 .122 (Gai. 5 Ed. prov.): Libertas omnibus rebus favorabilior est.

79 Plin., NH 7.39.128-9. Also see Suet., Gramm. 13 (Staberius Eros) and 15 (Lenaeus); D. 12.4.3.5 (Ulp. 26 Ed.); Tac., Ann. 13.27 (Paris).

${ }^{80}$ Suet., Vesp. 16.3; Virg., Ecl. 1.26-35.
} 
( $\$ 14.5$ and 2), slaves could be sold under the obligation to manumit (ut manumittatur); sold in trust against a payment from the slave's peculium or money borrowed to the purpose (emptio suis nummis); manumitted by testament under a condition of payment (statuliber); or left under a testamentary trust (fideicommissum) under the taker's obligation to manumit against payment. Many of these arrangements were put on firmer legal footing by the emperors, ${ }^{81}$ though it should be recalled that statuliberi already appear in the Law of the Twelve Tables. Under the Trajanic SC Rubrianum (AD 103), ${ }^{82}$ the praetor could declare a slave free if the fiduciary taker under a legacy would not free him and did not appear in court to explain himself (Buckland 1908: 611-20; Finkenauer 2010: 26-34). If they were not freed by their fiduciary buyer, slaves who bought their freedom with their own money (suis nummis) could claim their freedom in court under a rescript of Marcus Aurelius and Lucius Verus (AD 161-9, Buckland 1908: 636-40; Horsmann 1986; Finkenauer 2010: 44-50). ${ }^{83}$ And by a constitution of Marcus Aurelius and Commodus (AD c.178), a slave who was sold or, less often, donated to be manumitted by the new master, was automatically free if the master did not comply (Buckland 1908: 628-36; Finkenauer 2010: 34-44) ${ }^{84}$ This construction of a transfer ut manumittatur was particularly suited to cases of self-sale into slavery, which required the use of a proxy seller. The self-seller could negotiate the conditions of servitude and future manumission (including the grant of a peculium) by having the proxy seller transfer him under the condition ut manumittatur, for instance after a certain period of servitude or when a certain sum had been paid. Such a construction gave the self-seller legal redress, though still a slave, if the conditions were met but manumission did not follow. A similar but far older rule applied to statuliberi, who became free immediately once they either fulfilled the testamentary condition of paying money, rendering an accounting, serving for a certain period, etc., or were prevented from fulfilling that condition (Buckland 1908: 487-8, 492-505). In other words, slaves could actively proceed against their

${ }^{81}$ The causes for this development are not clear. A lessened credibility of mere moral commitments, favor libertatis, the greater importance accorded to will theories and by extension to testaments, or even the desire to raise the proceeds of manumission taxes may all have played a part.

${ }^{82}$ D. 40.5 .26 .7 (Ulp. 5 fideic.). $\quad{ }^{83}$ D. 40.1 .4 pr. (Ulp. 6 disp.) and following.

${ }^{84}$ D. 40.1 .20 pr. (Pap. 10 resp.); D. 40.8 .3 (Call. 3 cogn.); C. 4.57 .2 (Alex., AD 222); C. 4.57 .3 pr. (Alex., AD 224). 
masters in court on the strength of many manumission agreements, though not on a mere pactio. This forms an important departure from the rule that slaves had no capacity to appear in civil suits (Buckland 1908: 83-4; Garnsey 1981: 363). ${ }^{85}$ Such varied manumission arrangements imply negotiation between masters and slaves, but even more tellingly a concern for the possibility of enforcing the bargain.

Two final arrangements need mentioning because they clarify the limits of this system. The Roman law of civil procedure dictated that all judgments were expressed in terms of money, which might suggest the trick of colluding with a free person to bring a suit concerning the status of a slave (Buckland 1908: 653, 665). If the master proved slave status, the suit was lost and the damages would simply be paid. Yet in opposition to the general principle of pecuniary condemnation, Papinian explicitly states that a victorious master cannot be forced to accept money if he wishes to take away the slave. ${ }^{86}$ Negotiated manumission always depended on the will and assent of the master (Gardner 1993: 14). A second trick only strengthens the point. A slave could give someone a mandate to buy him and subsequently set him free. ${ }^{87}$ Such a mandate has essentially no legal force, although it may give rise to obligations if the slave has indeed been sold and transferred, that is to say if the master assents (Buckland 1908: 639-40; Heinemeyer 2013: 238-80). But since a slave has no authority to sell or transfer himself, ${ }^{88}$ and cannot irrevocably bind the master to a mandate to sell (which can always be withdrawn as long as there is no performance), it falls within the master's power to comply with the slave's scheme or not (Heinemeyer 2013: 270-1). For this reason, according to Ulpian, "In this case I should be no more liable on the mandate than I am forced to sell him." ${ }^{" 99}$ In the final analysis, manumission required the master's assent.

${ }^{85}$ D. 5.1 .53 (Herm. 1 epit.): slaves may inter alia appear in court against their masters in cases of (conditional) testamentary or fideicommissary manumission, fiduciary purchase with their own money (suis nummis), purchase with money loaned to the purpose of manumission, and to have an arbiter appointed to supervise the conditions of accounting.

${ }^{86}$ D. 40.12 .36 (Pap. 12 resp.): Dominus qui optinuit, si velit servum suum abducere, litis aestimationem pro eo accipere non cogetur. If he accepted the pecuniary condemnation however, the slave became a Junian Latin: C. 7.6.1.8 (Just., AD 531).

87 D. 17.1.19 (Ulp. 43 Sab.); D. 17.1.54 pr. (Pap. 27 quaest.); C. 4.361 (Diocl./Max., AD 293).

${ }^{88}$ A slave is never part of his own peculium: D. 33.8.16.1 (Afr. 5 quaest.).

${ }^{89}$ D. 17.1 .19 (Ulp. 43 Sab.): nec magis in hunc casum debeo mandati teneri, quam ut eum tibi venderem. 


\subsection{THE PECULIUM AS A FREEDOM FUND}

The linchpin of the Roman system of self-purchase by slaves is the peculium, the slave patrimony. That certain slaves were allowed the use of property that formally belonged to their master is again not uniquely Roman. The Delphic manumission inscriptions imply that the phenomenon was also known in the Greek world (Hopkins 1978: 147) and traces of a similar practice appear in Jewish law (Cohen 1951: 150-86). What is characteristically Roman, however, is the amount of legal attention devoted to the institution. In theory it could not exist as the slave had no relevant legal capacity; but in practice the jurists treated it in over 1,000 fragments of the Digest with their eyes wide shut. ${ }^{90}$ For the present purpose, only a few aspects matter. It has been noted that the peculium could be granted and taken away at any time, though this was undoubtedly circumscribed by social norms. Whether masters always knew what their slaves controlled is another matter entirely (Johnston 2002). Some placed their money in a bank, lent it to debtors, or sent assets abroad, and many will have had secret funds hidden away. ${ }^{91}$ The implication of rendering an accounting as a condition for manumission (\$14.2), with the insistence on accounting in good faith, is that "squaring up" was more important than the provenance of the funds. ${ }^{92}$ As noted, some peculation was assumed, but evidently outweighed by lower supervision costs.

Slave peculia could be extensive, containing "chattels, land, subslaves and their peculium, and even claims against debtors," or very small, consisting only of clothes or some livestock. ${ }^{93}$ Sizable holdings

90 D. 40.1.4.1 (Ulp. 6 disp.): "First, it seems that it cannot be properly said that someone is bought with his own money, since a slave cannot have his own money: but with closed eyes it should be thought that he has been purchased with his own money, as long as he is not bought with the money of the one who buys him" (et primo quidem nummis suis non proprie videtur emptus dici, cum suos nummos servus habere non possit: verum coniventibus oculis credendum est suis nummis eum redemptum, cum non nummis eius, qui eum redemit, comparator).

91 D. 16.3.1.33 (Ulp. 30 Ed.); D. 40.7 .40 .6 (Scaev. 24 dig.); D. 44.7 .14 (Ulp. 1 disp.).

92 D. 40.7.23.1 (Cels. 22 dig.).

93 D. 15.1.7.4 (Ulp. 29 Ed.): in peculio autem res esse possunt omnes et mobiles et soli: vicarios quoque in peculium potest habere et vicariorum peculium: hoc amplius et nomina debitorum. Clothes: D. 15.1.25 (Pomp. 32 Sab.). Livestock: Varro, RR 1.17.7 and 1.19.3. 
are attested for slaves in the imperial household, ${ }^{94}$ though the legal sources also contain references to private slaves owning money, wine, buildings, cattle, gold and silver, and vicarii or sub-slaves. ${ }^{95}$ Many slaves erected costly inscriptions from their own money (de suo) for themselves or for others: the masseur Arphocras, for instance, bought space in a columbarium for 80 denarii and an ossuary for 175 denarii. ${ }^{96}$ Slaves received some sort of allowance ${ }^{97}$ and there are glimpses of wage-earning or tenant slaves who made payments to their absent masters, ${ }^{98}$ presumably in exchange for greater independence. Alfenus reports that he was consulted on the case of a statuliber who paid off his duty to perform day labor in money. These money payments did not count toward fulfilling the manumission condition, Alfenus explained, just as a money payment from the slave tenant of a farm instead of a payment in kind would not count. ${ }^{99}$ Even Cato, who is not otherwise known as a considerate master, ran a paid brothel for his slaves and lent them money to invest in other slaves and share in the profit, both of which imply the grant of a peculium. ${ }^{100}$

Several authors have argued that Roman businesses were structured through the peculium to benefit from the legal advantages offered by the master's limited liability (Di Porto 1984; Cerami and Petrucci 2010: 61-7; Abatino et al. 2011). But in spite of occasional references, ${ }^{101}$ there is preciously little evidence outside of the legal texts ${ }^{102}$ that economic

94 e.g. CIL VI $5197=$ ILS 1514 (a dispensator Scurranus with $16+$ vicarii, AD 14-37); Suet., Otho 5.2; Plin., NH 33.52.145.

${ }_{95}$ Money: D. 19.1.38 pr. (Cels. 8 Dig.). Wine: D. 33.6.9.3 (Ulp. 23 Sab.). Buildings: D. 15.1.22 (Pomp. 7 Sab.); D. 33.8.6 pr. (Ulp. 25 Sab.). Cattle: D. 15.3.16 (Alf. 2 Dig.). Gold and silver: D. 14.4.5.13 (Ulp. 29 Ed.). Vicarii figure in sixty-four fragments from the Digests (Morabito 1981: 111 n. 605).

96 A direct link between the peculium and paying for an inscription de suo is found in several inscriptions: CIL II 6338ff; CIL II ${ }^{2}$ 7.981; CIL XI $6314=I L S$ 3581; AE 1903, 140. Arphocras: $A E$ 1980, 150 (AD c.50).

97 Sen., Ep. 80.8; Hor., Ep. 1.14.40; Petr., Sat. 75.4.

98 Wage-earning: D. 12.6.55 (Pap. 6 quaest.); D. 19.2.60.7 (Lab. 5 post.); D. 40.7.3.8 (Ulp. 27 Sab.) and possibly D. 33.7.19.1 (Paul. 13 resp.). Tenancy: D. 15.3 .16 (Alf. 2 dig.); D. 18.1.40.5 (Paul. 4 epit.); D. 20.1.32 (Scaev. 5 resp.); D. 26.7.32.3 (Mod. 6 resp.); D. 33.7.12.3 (Ulp. 20 Sab.); D. 33.7.18.4 (Paul. 2 Vit.); D. 33.7.20.1 (Scaev. 3 resp.); C. 4.14 .5 (Gord., AD 243).

99 D. 40.7 .14 pr. (Alf. 4 dig.). $\quad 100$ Plut., Cato 21.2 and 21.7.

101 Banking: Hipp., Refut. omn. haer. 9.7, but also see D. 14.5.8 (Paul. 1 Decr.). Pasturage: Varro, RR 2.10.5.

102 The Digest contains various examples of economic activity structured through the peculium. Shops: D. 14.4.5.13 (Ulp. 29 Ed.); D. 14.4.5.16-17 (Ulp. 29 Ed.) and possibly D. 15.1 .47 pr. (Paul. 4 Plaut.). Banks: D. 2.13.4.3 (Ulp. 4 Ed.). Inns and 
activity was purposely structured in this manner, with the institor model of direct agency appearing dominant instead (Aubert 1994; Fleckner 2010: 235; Mouritsen 2011: 175). Peculium-run businesses may have been rather small (Abatino and Dari-Mattiacci in this volume) and more often than not an extension of the family economy. Even so, peculia undoubtedly formed an important aspect of the Roman slave household, and it does not seem far-fetched to claim that most slaves held one, especially if they were involved in tasks that were difficult to monitor (Dari-Mattiacci 2013). Rather than an organizational principle for Roman businesses, the peculium appears to have been a reward or incentive for better work, both serving to ameliorate a slave's condition and to allow the prospect of eventual self-purchase. It was a recognized legal principle that the peculium served as a "freedom fund," and so a statuliber became free if he was blocked from the peculium which he needed to fulfill the condition of his release (Buckland 1908: 502-3). The use of sub-slaves is of particular interest in this regard. Horace explicitly connects the term vicarius to slave speech by opposing him to the co-slave (conservus) that such a slave actually is. ${ }^{103}$ Sub-slaves could be employed to perform their slave master's work, netting time for other activities, or to enhance the slave master's peculium, for instance by being hired out to others. Aside from vicarii working as farmers, sailors, captains, and shopkeepers (Morabito 1981: 112), the Digest also contains the sinister example of sub-slaves put to work as prostitutes. ${ }^{104}$ Perhaps the most revealing use of vicarii is that of delivering them pro libertate, in exchange for freedom, either by the slave who is seeking freedom or by a third party. ${ }^{105}$ Thus, it is tacitly assumed for such

stables: D. 4.9.7.6 (Ulp. 18 Ed.). Mule driving: D. 19.2.60.7 (Lab. 5 post.). Shipping: D. 4.9.3.3 (Ulp. 14 Ed.); D. 4.9.7.6 (Ulp. 18 Ed.); D. 9.4.19.2 (Paul. 22 Ed.); D. 14.1.1.22 (Ulp. 28 Ed.); D. 14.1.6 pr. (Paul. 6 brev.); D. 47.2 .42 pr. (Paul. 9 Sab.). Dye factory: D. 32.91 .2 (Pap. 7 resp.). Clothing factory: D. 14.4.5.15 (Ulp. 29 Ed.); D. 15.1.27 pr. (Gai. 9 Ed. prov.). Bakery: D. 33.7.18.1 (Paul. 2 Vit.). Managing conveyances: D. 11.6.3.6 (Ulp. 24 Ed.). Prostitution: D. 3.2.4.3 (Ulp. 6 Ed.).

103 Hor., Sat. 2.7.79-80. For the jurists, the term has a precise technical meaning: a slave belonging to the peculium of another slave. Vicarii appear in many inscriptions but the meaning is less clear there, since the term was also used as a functional description ("assistant," "underling") for slaves belonging to the imperial household, cities, or tax associations (Weaver 1972: 200-6).

${ }^{104}$ Hire: D. 14.3.11.8 (Ulp. 28 Ed.); D. 14.3 .12 (Iul. 11 dig.). Prostitution: D. 3.2.4.3 (Ulp. 6 Ed.), though it should be noted that the master slave is considered infamis after manumission.

105 Slave: D. 41.3.4.16 (Paul. 54 Ed.); D. 41.4 .9 (Iul. 3 Urs. Fer.). Third party: D. 19.5.5.2 (Paul. 5 quaest.). 
exchanges that a slave of equal market value is as good as any other slave, and the only question that concerns the jurists is what happens if title to the replacement slave is disturbed.

\subsection{ESTABLISHING THE PRICE OF FREEDOM}

It remains an open question whether Roman slaves paid a premium, a reduced fee (Morabito 1981: 57), or market price (Garnsey 1981: 364) for their freedom. All options are theoretically possible: a slave may have valued his freedom higher than a potential buyer, but the price may also have been lower out of liberality, or because the slave would not have required guarantees. Much will have depended on specific negotiations. The jurists assume an objective market price when discussing the replacement value, although they are certainly aware of subjective considerations. If a slave is killed, emotional attachment plays no part in establishing the damages, though it might have raised the cost of purchasing this specific slave, and the same rule applies if the value of a slave's labor is to be appraised. ${ }^{106}$ Freeing a slave in return for money does not lead to enrichment, as the money completely covers the loss of the slave, but if the slave pays more than his value, presumably the market value, then the master is enriched to the amount of the surplus. ${ }^{107} \mathrm{~A}$ captured slave who has been ransomed from the enemy by someone else and set free need only pay his true master his estimated market price to acquire freedom. ${ }^{108}$ If parents sold a child into slavery, Constantine allowed them to reclaim the child against payment of its value or delivery of a replacement slave, ${ }^{109}$ again stressing the connection between market price and freedom. For calculations concerning the Falcidian fourth, release under a fideicommissum, or manumission of someone else's slave by mistake, the market value is again generally used. In all, the overwhelming tendency among the jurists is to value slaves at their market price for replacement purposes.

106 D. 9.2.33 (Paul. 2 Plaut.); D. 7.7.6.2 (Ulp. 55 Ed.).

107 D. 15.3.2 (Iav. 12 Cass.); D. 15.3.3 pr. (Ulp. 29 Ed.). By implication, market value and slave are interchangeable while the surplus constitutes a gift from the peculium to the master.

108 D. 29.2.71 pr. (Ulp. 61 Ed.).

109 Fr. Vat. 34 (Const., AD 313); C.Th. 5.10 .1 (Const., AD 329). 
The scarcity of credible and comparable manumission prices makes it difficult to establish a relation between the market price and the price of freedom in practice. ${ }^{110}$ Almost all slave prices mentioned in the Digests are unusable as evidence (Buckland 1908: 8) ${ }^{111}$ and many of the literary prices are suspect. In Delphi, Hopkins (1978: 158-63) found evidence for a rising manumission premium for full freedom due to increased prices as a result of market integration. If anything, manumission prices seem to be on the high side as well in the documents from Roman Egypt, suggesting a premium, but the evidence does not allow for any conclusions. The following prices are merely given as an indication, ${ }^{112}$ but they do show that manumission and replacement at market value operate on the same plane, or put differently, that the price of freedom is not an order of magnitude higher than the market value of slaves.

Circumstantial support comes from relating slave prices to prices for other commodities. Ruffing and Drexhage (2008: 340-5) found that the somewhat believable documented slave prices could be expressed in terms of 250-1,000 day wages for the first century AD and 200-1,000 day wages for the second century. For Roman Egypt, where better data are always available, prices lay between 1,200-2,000 day wages in the first century, between $250-2,800$ day wages in the second century, and between 400-1,125 day wages in the third century, before the massive inflation of the last quarter of that century (Table 14.2). Converting slave prices to wheat equivalent, Scheidel (2005b: 2-6) arrived at prices that represented 2.7-3.2 years of income for a rural laborer in Roman Egypt. Diocletian's Edict on maximum prices of $\mathrm{AD} 301$ contains a schedule of slave prices, as well as ample figures on wages and daily necessities (Lauffer 1971;

${ }^{110}$ Interestingly, the Sumerian Code of Lipit-Ishtar from the nineteenth century BC contains a provision $(\$ 14)$ that a slave shall be freed if he compensates his master twofold.

111 Slave prices are mentioned in 133 fragments of the Digest. The price is almost always 10, with 5 being half a slave or a pledged slave, and 20 being two slaves, a skilled slave, or a case of mistake or deception. Justinianic price schedules aside, the only actual price seems to be the fixed sum of 20 aurei that was to be paid by slaves who had been set free under an invalid will yet wanted their freedom: D. 4.4 .31 (Pap. 9 resp.); D. 5.2.8.17 (Ulp. 14 Ed.); D. 5.2.9 (Mod., inoff. test.); D. 40.4 .47 pr. (Pap. 6 quaest.). Contra Morabito 1981: 54-9; Scheidel 2005b: 6.

112 See Ruffing and Drexhage 2008: 321-36 for the completest list to date. On the sale of slaves in Roman Egypt, see Straus 2004. 
Table 14.2. Some Roman-Egyptian slave prices (in silver dr.).

\begin{tabular}{lrrl}
\multicolumn{2}{l}{ Manumission prices have been bolded. ${ }^{113}$} & \\
\hline Year (AD) & Price & Age & Source \\
\hline c.80-100 & 1,161 & 23 & P. Oxy. LXXV 5051 \\
86 & 1,125 & - & P. Oxy. I 48 + XXXVIII 2843 \\
$91 / 92$ & 900 & 32 & P. Oxy. XXXVIII 2856 \\
101 & 1,000 & 17 & P. Turn. 19 \\
$107-15$ & 500 & $0-19$ & P. Strasb. VI 505 \\
$c .100-25$ & 700 & 4 & BGU XI 2111 \\
$\ldots$ & & & \\
212 & 1,600 & 19 & P. Oxy. XXXVI 2777 \\
221 & 2,200 & 34 & FIRA III 11 \\
221 & 2,200 & 14 & P. Vind. Bos. 7 \\
225 & 1,600 & 9 & SB XIV 11277 \\
234 & 2,200 & 25 & PSI III 182 \\
$c .235$ & 1,600 & - & P. Oxy. XLIII 3117 \\
\hline
\end{tabular}

Salway 2010). ${ }^{114}$ It suggests that a male unskilled slave between 16 and 40 (maximum price: 30,000 denarii) cost the equivalent of 4.8-6 years of unskilled day wages (maximum price: 20-25 denarii), at 250 working days per year. It is under debate whether slave labor and wage labor stood in direct competition, and if so for which occupations (Harper 2010: 212-14, Groen-Vallinga 2017: 280-2). But even so it is interesting to note that a slave working as a day laborerwhich included limited meals-would potentially earn back his purchase price within a period of years rather than decades. The Price Edict supplies enough information to fill out this amortization period by using a 'consumption basket' of daily necessities. Adapting the figures supplied by Allen (2009: 327-43) and assuming no rent payments, with lodgings provided by the master, the investment in an unskilled male slave of 18 years might be recouped between 4.7 years ("bare bones diet") and 7.7 years ("respectable diet"), assuming

113 Prices in talents and copper drachmae have been converted using the scale: 1 talent $=6,000$ copper drachmae $=100$ silver drachmae. For tax purposes, 300 copper dr. converted to 1 silver dr., but a conversion rate of $56: 1$ seems to have been used in practice (Johnson 1936: 282-3). Note that P. Oxy. XXXVIII 2856 mentions both prices, at a conversion rate closer to 69:1.

114 Since the Price Edict offers maximum prices, without explaining their provenance or their internal relation, the schedule should be used with care. Scheidel 1996; Harper 2010: 219-20. 
250 working days per year. A late legal source implies an awareness of this range: if a captive is ransomed from enemies, he has to repay the ransom price or work off the debt in five years' time. ${ }^{115}$ Skilled slaves may have earned more, but their value was higher as well, since skill level is an important determinant of market price. ${ }^{116}$ Diocletian's Edict expressly provides that the price for skilled slaves is at most double that of unskilled slaves, which corresponds to the differentiation between skilled (50-75 denarii per day) and unskilled labor (20-25 denarii per day), and so the range stays roughly the same. Interestingly enough, the high prices that are mentioned for certain exceptional slaves (doctors, grammarians, actors), fall in the same range when set against the comparably high figures for their wages: the ratio is roughly 0.2 to 7 years of wages. ${ }^{117}$ Needless to say, these figures need to be taken with a large grain of salt. Their purpose is merely to draw attention to the fact that the overall ratio is one to eight years of wages, tending to five to seven years, rather than twenty to thirty years.

How long, then, would a slave have to labor to purchase his freedom at a close to market price? Unfortunately, it is almost impossible to relate manumission prices to specific terms of servitude. Not a single source refers to the amount that a master would allow slaves to keep for themselves in the form of wages. Seneca states that a slave actor received 5 denarii and 5 modii of wheat for a show, but he does not mention the master's cut; Martial refers to a gratuity of 25 asses. ${ }^{118}$ Such figures are hardly enough to hazard a guess, and in any case the amount of wages will have differed from case to case. Other legal systems from antiquity such as Babylonian and Mosaic law mention relatively short terms of servitude, three to six years, although these relate mostly to debt bondage and legislation

115 C.Th. 5.7.2 = Const. Sirm. 16 (Hon., AD 408) = C. 8.50(51).20.2 (Hon., AD 409).

116 The jurists valued the use of a skilled slave against his market price, but the use of an unskilled slave against the daily wages earned by his usual work: D. 7.7.6 pr. (Ulp. 55 Ed.).

117 Doctor: 250,000 HS per year (Plin., NH 29.5.7, imperial physician), manumission 50,000 HS (CIL XI $5400=$ ILS 7812). Actor: 200,000 HS per year (Cic., Q. Rosc. 23), manumission 700,000 HS (Plin., NH 7.39.128). Grammarian: 100,000 HS per year (Suet., Gramm. 17), sale 700,000 HS (Plin., NH 7.39.128).

118 Sen. Ep. 80.5: Ille qui in scaena latus incedit et haec resupinus dicit [...] servus est, quinque modios accipit et quinque denarios; Mart. 10.75: Sportula [...] quadrantibus arida centum [...] puero diximus esse datam. 
on periodic debt remission (Wiedemann 1985: 166; Chirichigno 1993). ${ }^{119}$ Roman law is less forthcoming. As mentioned, the manumission prices from the Digest yield no information; similarly, the terms of servitude provide little insight (Wiedemann 1985: 169-74). Testamentary provisions for terms of one, two, three, five, seven, ten, and even fifteen years are mentioned, as well as provisions for payment of certain sums during or within three, five, or ten years. But without any particulars of a slave's age and status, such clauses mean very little. Neither provisions that a slave is to be released after a certain period of time (examples are one, two, three, five, eight, ten, or twelve years), nor clauses that he is to be released when the heir or the taker under a legacy dies or comes of age, can be related to a specific period of servitude. If a manumission clause is coupled to a slave's age, it is almost always the 30 years of age that corresponds to the lex Aelia Sentia. ${ }^{120}$ The one exception occurs in a rescript from Alexander Severus considering a slave girl named Firmia who was sold at age 7 , to be released at age $25 .^{121}$

The single explicit reference to a common term of servitude comes from Cicero, who informs the senate that it entertains some hope of freedom after enduring six years of slavery, which is longer than diligent captives and frugal slaves usually suffer. ${ }^{122}$ Cicero is referring to the time that has passed since Caesar crossed the Rubicon, and so the period is of limited value (Mouritsen 2011: 137). Nevertheless, the reference would fall flat if slaves only had a chance of freedom after, say, thirty productive years. Considering the social advantage of gaining freedmen while recapitalizing, relatively short terms of servitude seem likely for those who became slaves later in life, while the practice of manumitting certain slaves at an early age (\$14.3) may have been the lot of those born into slavery or enslaved at a very young age. Again, it should be remembered that some slaves were never freed.

119 Codex Hammurabi 117 (in the fourth year); Exod. 21.2; Deut. 15.12-18; Philo, Spec. leg. 2.84 (in the seventh year).

120 D. 10.2.39.2 (Scaev. 1 resp.); D. 34.5.29(30) (Scaev. 18 dig.); D. 40.4 .46 (Pomp. 7 var. lect.); D. 40.7.13.5 (Iul. 43 dig.).

121 C. 4.57 .3 pr. (Alex., AD 224).

122 Cic., Phil. 8.32: Etenim, patres conscripti, cum in spem libertatis sexennio post sumus ingressi diutiusque servitutem perpessi, quam captivi servi frugi et diligentes solent. 


\subsection{PATRONS AND FREEDMEN}

Hopkins's question, "why did the Romans free so many slaves?," is best answered by a model in which the benefits of allowing slaves autonomy by the undisturbed use of their peculia, while factoring in the cost of peculation, outweigh the gains of brute exploitation. It implies that value extraction and recapitalization are delayed until an agreed-upon price has been met, because a slave cum peculio will eventually outperform a slave sine peculio (Alföldy 1972: 360-2). This scenario is not so unlikely, particularly when supervision costs are taken into account (Dari-Mattiacci 2013), as successful manumission deals inspire confidence in other slaves, leading to better work and subservience. But aside from the material benefit of better work at lesser cost, and the immaterial benefit of strengthened social peace, furthered by making some manumission agreements actionable, there is another mechanism at work to ensure that masters keep their word. The loss of a slave is sweetened by the acquisition of a freedman. ${ }^{123}$

Few parts of Roman law are as convoluted as the law of patronage. The rights of patrons take a number of forms, and these rights also vary considerably according to the type of manumission. The difference between slaves manumitted as citizens and as Junian Latins has already been mentioned ( $\$ 14.4$ ), but even for formally manumitted slaves, the legal relationship to their patron was contingent on the mode and conditions of manumission. Freedmen manumitted directly and among the living out of kindness or generosity remained firmly under their patron's control and supervision. All family relations were destroyed by slavery, and so the manumittor was legally closest to a parent, to whom a duty of obedience and deference was owed (Mouritsen 2011: 36-51). ${ }^{124}$ But as a general rule, a patron who

\footnotetext{
123 The patron's patrimony is enriched by acquiring a freedman. Thus, a manumittor in good faith of a slave that was transferred to him in error is enriched to the value of the operae and his claim to the freedman's inheritance: D. 12.6.65.8 (Paul. 17 Plaut.). From the palingenesis, it is clear that the far too general statement in D. 50.17.126.1 (Ulp. $15 \mathrm{Ed}$.), that no one is enriched who acquires a freedman, initially only referred to the Sc. Iuventianum of AD 129 concerning the vindicatio caducorum. See D. 5.3.20.6c (Ulp. 15 Ed.); D. 5.3.23 pr. (Ulp. 15 Ed.). A counter argument is not provided by D. 19.5.5.5 (Paul. 5 quaest.) either, since the reason why the freedman's value is not calculated in that particular case, is that the action is limited to quanti interest mea servum habere in the first place.

124 The duty of obsequium covers any number of rules, running from an inability to sue the patron in certain suits or raise certain defenses, to an obligation enforced by
} 
had received compensation for manumission, be it in payment or as taker under a fideicommissum, had fewer rights against his freedman (Garnsey 1981: 363-4). By extension, a trustee owner such as the transferee ut manumittatur or the buyer in an emptio suis nummis had even fewer rights, since he was merely lending his name to the manumission and not making any personal sacrifice at all. ${ }^{125}$ Finally, the slave who was freed by testament, the orcinus, was under little obligation at all (Loreti-Lorini 1925; Champlin 1991: 139) since his true patron was dead and the patron's heir, being next in line, had made no sacrifice nor willed the manumission. All the more reason existed to apply this rule if a slave was freed as a statuliber by testament, for instance under the condition of rendering an accounting, paying a sum of money, or working a number of years, since the heir even gained by the process when compared to direct manumission. If and when the condition was met, the former statuliber became a freedman of the deceased testator and not of the testator's heir.

Within this continuum, two categories of rights stand out for the present purpose since they carry a direct monetary value. These are claims on day labor or services (operae) and claims on the estate of a freedman upon his death, either in the form of a right to intestate succession or in the form of a claim for possession in contravention of the will (bonorum possessio contra tabulas). An overview is provided in the following, rudimentary table (Table 14.3).

The claim to labor duties may seem paramount among a patron's rights since it ensures the continued services of a freedman after manumission. But this is not the case. Operae could only be imposed upon freedmen who had been manumitted for free, and then only if they had promised or sworn to perform such duties (Garnsey 1981: 364; Gardner 1993: 20, 29-32). ${ }^{126}$ They could not be imposed if the master had accepted any money in return for manumission or had only served as a trustee manumittor, at least since the time of Hadrian (Morabito 1981: 168-9). In other words, the obligation to perform operae was mutually exclusive with paid-for manumission. It appears

public law to treat patrons with respect (Gardner 1993: 23-5). Similar considerations of the "parental" nature of the relationship underlie a freedwoman's need for permission to marry, reciprocal obligations of tutelage, and reciprocal claims for maintenance (alimenta) between patron and freedman.

125 D. 40.1 .4 .7 (Ulp. 6 disp.).

126 D. 38.1.7.2 (Ulp. 28 Sab.); D. 38.1.31 (Mod. 1 reg.); D. 40.4 .36 (Paul. 7 Plaut.). 
Table 14.3. Patron rights and the effects of manumission. Adapted from LoretiLorini 1925

\begin{tabular}{|c|c|c|c|c|c|}
\hline \multirow{2}{*}{$\begin{array}{l}\begin{array}{l}\text { Manumission } \\
\text { occurred... }\end{array} \\
\text { Inter vivos, and }\end{array}$} & \multicolumn{5}{|c|}{ The patron acquires a right to... } \\
\hline & $\begin{array}{l}\text { Labor } \\
\text { (operae) }\end{array}$ & $\begin{array}{l}\text { Intestate } \\
\text { succession }\end{array}$ & $\begin{array}{l}\text { Overrule a } \\
\text { testament }\end{array}$ & $\begin{array}{l}\text { Be maintained } \\
\text { (alimenta) }\end{array}$ & $\begin{array}{l}\text { Deference } \\
\text { (obsequium) }\end{array}$ \\
\hline - for free & $\mathrm{Yes}^{127}$ & $\mathrm{Yes}^{128}$ & $\mathrm{Yes}^{129}$ & $\mathrm{Yes}^{130}$ & $\mathrm{Yes}^{131}$ \\
\hline - by pactio & $\mathrm{No}^{132}$ & $\mathrm{Yes}^{133}$ & $\mathrm{Yes}^{134}$ & Yes? ${ }^{135}$ & $\mathrm{Yes}^{136}$ \\
\hline $\begin{array}{l}\text { - by transfer to } \\
\text { be freed }\end{array}$ & $\mathrm{No}^{137}$ & Yes? ${ }^{138}$ & $\mathrm{Yes}^{139}$ & Yes? ${ }^{140}$ & Yes $^{141}$ \\
\hline $\begin{array}{l}\text { (ut manumittatur) } \\
\text { - by purchase suis } \\
\text { nummis }\end{array}$ & $\mathrm{No}^{142}$ & $\mathrm{No}^{143}$ & $\mathrm{No}^{144}$ & $\mathrm{No}^{145}$ & $\mathrm{No}^{146}$ \\
\hline
\end{tabular}

to have been the functional equivalent of borrowing the manumission price from the master and paying it off in instalments. Freedmen operae are accounted in labor days while the obligation to perform a certain number of labor days as a slave is conversely mentioned as a possible condition for manumission. ${ }^{147}$ The analogy between paying before and paying after manumission through labor is strengthened by the fact that freedmen could agree to pay a sum of money instead of performing labor, though patrons could not force them to do so

127 C. 6.3 .1 (Sev./Ant., AD 204).

128 Gai., Inst. 3.41; D. 26.4 .3 pr. (Ulp. 38 Sab.); D. 34.5.9(10).2 (Tryph. 21 disp.).

129 Gai., Inst. 3.41.

130 D. 25.3.5.18 (Ulp. 2 cons.); C. 6.3 .1 (Sev./Ant., AD 204).

131 D. 37.15 .7 .4 (Ulp. 10 Ed.); D. 38.2.1 pr. (Ulp. 42 Ed.); D. 44.4.4.16 (Ulp. 76 Ed.); D. 47.2.92(91) (Lab./Paul. 2 pith.); C. 2.41(42).2 (Just., AD 531); C. 6.7 .1 (Ant., AD 214).

132 C. 6.3 .3 (Sev./Ant., AD 206). $\quad{ }^{133}$ C. 6.4 .1 pr. (Sev./Ant., AD 210).

134 C. 6.4 .1 pr. (Sev./Ant., AD 210) contra D. 38.2.3.4 (Ulp. $41 E d$.), which is generally amended.

135 By inference: no direct source available.

136 D. 37.15 .3 (Marc., resp.); C. 6.6 .3 (Alex., AD 223).

137 C. 6.3 .2 (Sev./Ant., AD 205); D. 38.1 .13 pr. (Ulp. 38 Ed.).

138 By inference: no direct source available. $\quad{ }^{139}$ D. 38.2.3.3 (Ulp. 41 Ed.).

140 By inference: no direct source available. $\quad{ }^{141}$ D. 2.4 .10 pr. (Ulp. $5 E d$.).

${ }^{142}$ C. 6.3 .8 (Alex., AD 224). $\quad{ }^{143}$ C. 6.4.4.4 (Just., AD 531).

144 C. 6.4 .1 pr. (Sev./Ant., AD 210); C. 6.4.4.4 (Just., AD 531).

145 D. 25.3.5.22 (Ulp. 2 cons.).

146 D. 2.4 .10 pr. (Ulp. 5 Ed.); D. 37.15 .3 (Marc., resp.); C. 6.3 .8 (Alex., AD 224).

147 D. 38.1.3.1 (Pomp. 6 Sab.); D. 38.1.15.1 (Ulp. 38 Ed.); D. 40.7.4.4 (Paul. 5 Sab.). Also see D. 40.7.14.1 (Alf. 4 dig.). 
Table 14.3. Continued

\begin{tabular}{|c|c|c|c|c|c|}
\hline \multirow{2}{*}{$\begin{array}{l}\text { Manumission } \\
\text { occurred... }\end{array}$} & \multicolumn{5}{|c|}{ The patron acquires a right to... } \\
\hline & $\begin{array}{l}\text { Labor } \\
\text { (operae) }\end{array}$ & $\begin{array}{l}\text { Intestate } \\
\text { succession }\end{array}$ & $\begin{array}{l}\text { Overrule a } \\
\text { testament }\end{array}$ & $\begin{array}{l}\text { Be maintained } \\
\text { (alimenta) }\end{array}$ & $\begin{array}{l}\text { Deference } \\
\text { (obsequium) }\end{array}$ \\
\hline By testament, and & $\begin{array}{l}\text { Labor } \\
\text { (operae) }\end{array}$ & $\begin{array}{l}\text { Intestate } \\
\text { succession }\end{array}$ & $\begin{array}{l}\text { Overrule a } \\
\text { testament }\end{array}$ & $\begin{array}{l}\mathrm{Be} \\
\text { maintained } \\
\text { (alimenta) }\end{array}$ & $\begin{array}{l}\text { Deference } \\
\text { (obsequium) }\end{array}$ \\
\hline - directly (orcinus) & $\mathrm{No}^{148}$ & Yes $^{149}$ & Yes $^{150}$ & $\mathrm{No}^{151}$ & Some ${ }^{152}$ \\
\hline - by fideicommissum & $\mathrm{No}^{153}$ & Yes $^{154}$ & Yes $^{155}$ & $\mathrm{No}^{156}$ & Some ${ }^{157}$ \\
\hline
\end{tabular}

(Morabito 1981: 91-2). ${ }^{158}$ Again, the amount of operae owed would have been a matter of negotiation (Verboven 2012: 97). Seen in this light, there is little economic difference between manumission among the living under the imposition of operae, and manumission by testament under the condition to perform a number of services or pay a sum of money. The legal difference, however, is that manumission is already complete under the first option, while slavery

148 D. 38.1.13.1 (Ulp. 38 Ed.). Changed by Justinian so that a patron's son could impose operae (Loreti-Lorini 1925: 53). See D. 38.2.29.1. (Marc. 9 inst.); D. 40.5.33 pr. (Paul. 3 fideic.).

${ }^{149}$ Gai., Inst. 3.41. $\quad{ }^{150}$ Gai., Inst. 3.41.

151 The argument is that a slave who was to be released under a fideicommissum that the taker neglected to fulfill was declared free under the Sc. Rubrianum of AD 103 and given an equal position to that of an orcinus: D. 40.5.26.7 (Ulp. 5 fideic.); D. 40.5 .5 (Paul. 57 Ed.). By extension, the same held true for a slave bought suis nummis whom his fiduciary master would not free: D. 5.1 .67 (Ulp. 6 disp.). The true orcinus cannot have been worse off than these orcini by analogy. Therefore, there probably was no obligation to provide alimenta or act with full deference. See Loreti-Lorini 1925: 35-41. 152 See the previous footnote.

153 D. 38.1.7.4 (Ulp. 28 Sab.); D. 38.1.13.1 (Ulp. 38 Ed.); D. 38.1 .42 (Pap. 9 resp.); D. 38.1 .47 (Val. 6 fideic.); D. 38.2.29 pr. (Marc. 9 inst.); C. 6.3 .5 (Ant., AD 212); C. 6.4.4,7 (Just., AD 531). Changed by Justinian so that a patron's son could impose operae (Loreti-Lorini 1925: 53). See D. 38.2.29.1. (Marc. 9 inst.); D. 40.5.33 pr. (Paul. 3 fideic.). Sab.).

154 Fr. Vat. 225 (Pap. 11 quaest.); D. 38.2 .29 pr. (Marc. 9 inst.); D. 38.16.3.1 (Ulp. 14

155 Fr. Vat. 225 (Pap. 11 quaest.); D. 38.2 .29 pr. (Marc. 9 inst.); C. 6.13 .1 (Gord., AD 239).

156 D. 25.3.5.22 (Ulp. 2 cons.); C. 6.4.4.7 (Just., AD 531).

157 D. 2.4 .9 (Paul. 4 Ed.); C. 6.3 .5 (Ant., AD 212); C. 6.7.1 (Ant., AD 214).

158 D. 38.1.32 (Mod. 1 reg.); D. 38.1 .39 pr. (Paul. 7 Plaut.). 
continues under the second option, albeit under the unassailable position of a statuliber.

The paramount right of the patron, then, lies in the claim to inherit part of the estate of a freedman (Gardner 1993: 21-3) in addition to either receiving a manumission price or imposing operae. This claim travelled along the male line, ${ }^{159}$ ensuring that testamentary manumission, for example, did not overly diminish the family fortune. A freedman could only exclude his patron from inheriting by leaving the inheritance to his freeborn natural children. Even then, strengthening a patron's right to sizable estates (over 100,000 sesterces), the Augustan lex Papia Poppaea of AD 9 provided that a patron was entitled to a share equal to that of the freedman's children, while it took three surviving freeborn children to exclude the patron completely. In light of the regular age at manumission, plausibly between 30 and 40, complete exclusion was possible but perhaps not likely. This is even more true for women, who tended to be manumitted at a later age (Gardner 1993: 22; Scheidel 1997: 167-8). ${ }^{160}$ In addition, it was made legally difficult to resort to subterfuge to escape the patronal claim. Donating assets to children prior to death would be of no avail, since two actions were in place by the first century to rescind alienations by a freedman that could defraud the patron, further protecting his interest (Lenel 1927: 352-3; Gardner 1993: 23). ${ }^{161}$

This well-protected expectation of inheritance further strengthened the predilection of masters to delay extraction from their slaves until the payment of a manumission price, when they would receive replacement value and gain a freedman, instead of settling for full exploitation of a slave's labor (Table 14.4). Manumission did not amount to a full loss of the slave's earning capacity. In fact, a patron might benefit if a freedman did well for himself, which in turn ensured a continuing supervision that was desirable to the state.

159 The claim to a Junian Latin's inheritance was a simple patrimonial right that did not follow the rules of agnatic succession, but rather the normal rules of inheritance. Gai., Inst. 3.58 and following.

160 Freedwomen would have had to acquire the ius quattuor liberorum first (Kübler 1909), freeing them from their patron's tutelage by giving birth to four freeborn children, before they could make their own testament and even think of bypassing their patron. Considering the pattern of female manumission past childbearing age, acquisition of this right must have been limited to exceptional cases of early manumission. An example is perhaps found in CIL VI 10246 (Septimia Dionisias).

${ }^{161}$ The Fabian and Calvisian actions: D. 38.5 rubr. and C. 6.5 rubr. 
Table 14.4. Claims to freedman inheritance (Gai., Inst. 3.40-3.44 and 3.56; Ulp., Epit. 29.1-29.3).

\begin{tabular}{ll}
\hline Freedman has.... & Patron receives... \\
\hline Status of Junian Latin & All \\
No heres suus & All \\
Extraneus as heir (not a child) & Half \\
1 Child as heir and under 100,000 HS & Nothing \\
1 Child as heir and 100,000+ HS & Half \\
2 Children as heir and 100,000+ HS & One-third \\
3 Children as heir and 100,000+ HS & Nothing \\
\hline Freedwoman has... & Patron receives... \\
\hline No testament & All \\
Testament, less than 4 children & Patron decides \\
Testament, 4 living children & One-fifth \\
Testament, 3 living children, 1 dead & One-quarter \\
Testament, 4 dead children & All \\
\hline
\end{tabular}

This legal structure also explains why the remainder of the peculium could be handed to a freedman if anything was left after paying the freedom price. Patrons might confidently expect that after serving as an incentive and a freedom fund, the money would serve as venture capital (Garnsey 1981: 367-70; Mouritsen 2011: 176-80), to be returned to the family fortune with interest in good time. Since many skilled freedmen went on to work in the family business, capital accumulation could be monitored by the patron and was safeguarded by economic family ties (Verboven 2012: 98, Groen-Vallinga 2017: 146-52).

The one modality that escapes this framework is the emptio suis nummis (Heinemeyer 2013). Recognized by Marcus Aurelius, in this legal construction the slave was purchased by a fiduciary buyer for the express purpose of manumission, with money coming either from the slave's peculium or borrowed to the purpose. The seller was not manumitting the slave and so he did not become patron, while the buyer merely lent his name to the arrangement and made no sacrifice, leading to a near-complete loss of patron's rights including the right to inherit. This particular arrangement would seem to defeat the entire purpose of manumission for the original owner. Why not revoke the peculium, or even contract with the slave through a 
manumission pact, retaining the patron rights, instead of selling the slave to a fiduciary buyer? As with slaves freed under the condition of rendering an accounting-necessary to truthfully establish the size of an inheritance-some slaves will have had enough power and influence that the realization of replacement value from their no doubt hidden peculia required the surrender of patron rights. In this view, emptio suis nummis is not the starting point of legal development toward actionable manumission agreements, but rather the secondcentury endpoint. Instead of an unattractive proposition that was to be avoided in favor of other modalities (Gardner 1993: 37), or an anomaly (Mouritsen 2011: 173-4), its existence is testament to the bargaining power of certain well-placed slaves (Morabito 1981: 166-7). It put the enforceability of manumission arrangements made inter vivos on an equal level to that of testamentary arrangements and effectively neutralized almost all of a patron's claims. As such, it formed a logical pinnacle to the Roman system of negotiated freedom payments.

\subsection{CONCLUSION}

Conditional manumissions are known from the Hellenistic world and Roman Egypt (Zelnick-Abramovitz 2005). This chapter has suggested that the Roman lawyers, at least, considered the fulfillment of certain conditions the normal precursor to Roman manumission as well. Important differences exist between Greece, Egypt, and Rome, particularly with regard to the residual power over conditionally freed slaves, but the general point stands that relations between masters and slaves were formalized by negotiations and agreements concerning manumission. By enshrining an otherwise merely morally binding agreement in a testament, it became enforceable by the slave after his master's death. Gradually, as a result of imperial intervention, most manumission agreements made inter vivos became enforceable as well. The general effect of setting conditions prior to manumission was that a patron's hold over his freedman was lessened; or put differently, that a patron who accepted a price for freedom lost part of his bundle of rights. Aside from the emptio suis nummis, however, the most important patron right remained intact, in the form of an expectancy to inherit. 
Agreements between master and slave could concern the period of servitude, but more often referred to a manumission price. This price was paid from a slave's peculium, assets which masters allowed slaves to hold as their own (Garnsey 1981: 364). Serving both as an incentive and as a freedom fund, the slave peculium and the concomitant social practice of purchasing freedom explain why the Romans freed so many slaves. Though it is difficult to relate the size of the peculium to the proceeds of a slave's labor or the duration of slavery, its social importance can hardly be underestimated. It gave slaves an interest in their labor and the hope of advancement on the one hand, while reducing supervision costs, increasing security and raising productivity for their masters on the other. Though there was no legal guarantee of tenure, the peculium and the negotiations and agreements surrounding it show that at least a certain class of Roman slaves, that is to say those encountered in literary and epigraphic sources, rose well above the status of socially dead instrumentum vocale. The practice of frequent and early manumission in exchange for a negotiated and agreed upon price does not make the Roman slave system any less brutal or exploitative during the period of enslavement. But it does help to understand why masters, slaves, and freedmen, living in close proximity, largely succeeded in maintaining social order under the Roman empire. ${ }^{162}$

\section{REFERENCES}

Abatino, Barbara, Giuseppe Dari-Mattiacci, and Enrico C. Perotti. 2011.

"Depersonalization of business in ancient Rome." 31 Oxford Journal of Legal Studies 365-89.

Alföldy, Géza. 1972. "Die Freilassung von Sklaven und die Struktur der Sklaverei in der römischen Kaiserzeit." 2 Rivista Storica dell'Antichita 97-129; repr. with add. in Helmuth Schneider, ed., Sozial- und Wirtschaftsgeschichte der römischen Kaiserzeit, Darmstadt: WBG 1981, 336-71.

Alföldy, Géza. 2011. Römische Sozialgeschichte, 4th edn. Stuttgart: Steiner.

\footnotetext{
${ }^{162}$ Research for this chapter was conducted under grant 400-09-009 from the Netherlands Organisation for Scientific Research (NWO).
} 
Allen, Robert C. 2009. "How prosperous were the Romans? Evidence from Diocletian's Price Edict (AD 301)," in Alan K. Bowman and Andrew Wilson, eds, Quantifying the Roman Economy: Methods and Problems. Oxford: Oxford University Press, 327-45.

Arzt-Grabner, Peter. 2010. "'Neither a truant nor a fugitive': some remarks on the sale of slaves in Roman Egypt and other provinces," in Traianos Gagos, ed., Proceedings of the 25th International Congress of Papyrology. Ann Arbor: Scholarly Publishing Office, 21-32.

Aubert, Jean-Jacques. 1994. Business Managers in Ancient Rome: A Social and Economic Study of Institores, 200 B.C.-A.D. 250. Leiden/New York: Brill.

Bagnall, Roger S., and Bruce W. Frier. 1994. The Demography of Roman Egypt. Cambridge: Cambridge University Press.

Bradley, Keith R. 1987. Slaves and Masters in the Roman Empire: A Study in Social Control. Oxford: Oxford University Press.

Bradley, Keith R. 1994. Slavery and Society at Rome. Cambridge: Cambridge University Press.

Buckland, William W. 1908 [repr. 1970]. The Roman Law of Slavery. Cambridge: Cambridge University Press.

Cerami, Pietro, and Aldo Petrucci. 2010. Diritto commerciale romano: profilo storico, 3rd edn. Turin: Giappichelli.

Champlin, Edward. 1991. Final Judgments: Duty and Emotion in Roman Wills, 200 B.C.-A.D. 250. Berkeley: University of California Press.

Chirichigno, Gregory C. 1993. Debt Slavery in Israel and the Ancient Near East. Sheffield: Sheffield Academic Press.

Cohen, Boaz. 1951. "Peculium in Jewish and Roman law." 20 Proceedings of the American Academy for Jewish Research 135-234.

Dari-Mattiacci, Giuseppe. 2013. "Slavery and information." 73 Journal of Economic History 79-116.

Di Porto, Andrea. 1984. Impresa collettiva e schiavo 'manager' in Roma antica (II sec. a.C.-II sec. d.C.). Milan: Giuffrè.

Duff, Arnold M. 1928. Freedmen in the Early Roman Empire. Oxford: Clarendon Press.

Emmerson, Allison A. C. 2011. "Evidence for Junian Latins in the tombs of Pompeii?” 24 Journal of Roman Archaeology 161-90.

Fenoaltea, Stefano. 1984. "Slavery and supervision in comparative perspective: a model." 44 Journal of Economic History 635-68.

Finkenauer, Thomas. 2010. Die Rechtsetzung Mark Aurels zur Sklaverei. Stuttgart: Franz Steiner.

Finley, Moses I. 1985 [repr. 1999]. The Ancient Economy, 2nd edn. Berkeley: University of California Press.

Fleckner, Andreas M. 2010. Antike Kapitalvereinigungen. Ein Beitrag zu den konzeptionellen und historischen Grundlagen der Aktiengesellschaft. Cologne: Böhlau. 
Gardner, Jane F. 1993. Being a Roman Citizen. London/New York: Routledge. Garnsey, Peter. 1981. "Independent Freedmen and the Economy of Roman Italy under the Principate." 63 Klio 359-71.

Groen-Vallinga, Miriam J. 2017. The Roman World of Work, (diss. Leiden). Rotterdam: Optima Grafische Communicatie.

Günther, Sven. 2008. "Vectigalia nervos esse rei publicae": Die indirekten Steuern in der Römischen Kaiserzeit von Augustus bis Diokletian. Wiesbaden: Harrassowitz.

Harada, Keikichi. 1939a. "Textkritische Studien zur adsignatio liberti orcini.” 59 Zeitschrift der Savigny-Stiftung 498-508.

Harada, Keikichi. 1939b. "Zwei Quellenstellen zum Patronatsrecht," in Festschrift Paul Koschaker I. Weimar: Böhlau, 401-3.

Harper, Kyle. 2008. "The Greek census inscriptions of late Antiquity." 98 Journal of Roman Studies 83-119.

Harper, Kyle. 2010. "Slave prices in late antiquity (and in the very long term)." 59 Historia 206-38.

Harris, William V. 1980. "Toward a study of the Roman slave trade." 36 Memoirs of the American Academy in Rome 117-40.

Harris, William V. 1999. "Demography, geography and the sources of Roman slaves." 89 Journal of Roman Studies 62-75.

Heinemeyer, Susanne. 2013. Der Freikauf des Sklaven mit eigenem GeldRedemptio suis nummis. Berlin: Duncker \& Humblot.

Hopkins, Keith. 1978. Conquerors and Slaves. Cambridge: Cambridge University Press.

Hopkins, Keith. 1993. "Novel evidence for Roman slavery." 138 Past \& Present 3-27.

Horsmann, Gerhard. 1986. 'Die 'divi fratres' und die 'redemptio servi suis nummis' (zu den Motiven der epistula ad Urbium Maximum, Dig. 40,1,4)." 35 Historia 308-21.

Johnson, Allan C. 1936. Roman Egypt to the reign of Diocletian, in Frank Tenney, ed., An Economic Survey of Ancient Rome, vol. II. Baltimore: Johns Hopkins University Press.

Johnston, David. 2002. "Peculiar questions," in Paul McKechnie, ed., Thinking Like a Lawyer: Essays on Legal History and General History for John Crook on his Eightieth Birthday. Mnemosyne suppl. 231. Brill: Leiden, 5-13.

Kaser, Max. 1971. Das römische Privatrecht. Vol. I: Das altrömische, das vorklassische und klassische Recht, 2nd edn. Munich: Beck.

Kleijwegt, Marc. 2002. "Cum vicensimariis magnam mantissam habet (Petronius Satyricon 65.10).” 123 American Journal of Philology 275-86.

Kleijwegt, Marc. 2012. "Deciphering freedwomen in the Roman Empire," in Sinclair Bell and Teresa Ramsby, eds, Free at Last! The Impact of Freed Slaves on the Roman Empire. London: Bloomsbury, 110-29. 
Koops, Egbert. 2012. "Second-rate citizens: Junian Latins and the constitutio Antoniniana." 19 Maastricht Journal of European and Comparative Law 223-39.

Kübler, Bernhard. 1909. "Über das Jus liberorum der Frauen und die Vormundschaft der Mutter. Ein Beitrag zur Geschichte der Rezeption des römischen Rechts in Ägypten.” 30 Zeitschrift der Savigny-Stiftung 154-82.

Lauffer, Siegfried. 1971. Diokletians Preisedikt. Berlin: De Gruyter.

Lenel, Otto. 1927 [repr. 2010]. Das edictum perpetuum. Ein Versuch zu seiner Wiederherstellung, 3rd edn. Leipzig: Tauchnitz.

Liebs, Detlef. 2000. "Das testament des Antonius Silvanus, römischer Kavallerist in Alexandria bei Ägypten, aus dem Jahr 142 n. Chr.," in Klaus Märker, ed., Festschrift für Weddig Fricke zum 70. Geburtstag. Freiburg: Alber, 113-28.

Lopez Barja de Quiroga, Pedro. 1998. "Junian Latin: status and number.” 86 Athenaeum 133-64.

Loreti-Lorini, Bradamante. 1925. "La condizione del liberto orcino nella compilazione giustinianea." 34 Bullettino dell'Istituto di Diritto Romano 29-66.

Morabito, Marcel. 1981. Les réalités de l'esclavage d'après le Digeste. Paris: Belles Lettres 1981.

Mouritsen, Henrik. 2005. "Freedmen and decurions: epitaphs and social history in imperial Italy." 95 Journal of Roman Studies 38-63.

Mouritsen, Henrik. 2011. The Freedman in the Roman World. Cambridge: Cambridge University Press.

Patterson, Orlando. 1982. Slavery and Social Death: A Comparative Study. Cambridge, MA: Harvard University Press.

Roth, Ulrike. 2010. "Peculium, freedom, citizenship: golden triangle or vicious circle? An act in two parts," in Ulrike Roth, ed., By the Sweat of your Brow: Roman Slavery in its Socio-Economic Setting (BICS Suppl. 109). London: Institute of Classical Studies, 91-120.

Ruffing, Kai, and Hans-Joachim Drexhage. 2008. "Antike Sklavenpreise," in Peter Mauritsch, ed., Antike Lebenswelten: Konstanz-WandelWirkungsmacht. Festschrift für Ingomar Weiler zum 70. Geburtstag (Philippika 25). Wiesbaden: Harrassowitz, 321-51.

Salway, Benet. 2010. "Mancipium rusticum sive urbanum: the slave chapter of Diocletian's edict on maximum prices," in Ulrike Roth, ed., By the Sweat of your Brow: Roman Slavery in its Socio-Economic Setting (BICS Suppl. 109). London: Institute of Classical Studies, 1-20.

Scheidel, Walter. 1996. "Reflections on the differential valuation of slaves in Diocletian's Price Edict and in the United States." 15 Münstersche Beiträge zur Antiken Handelsgeschichte 67-79.

Scheidel, Walter. 1997. "Quantifying the sources of slaves in the early Roman Empire.” 87 Journal of Roman Studies 156-69. 
Scheidel, Walter. 2005a. "Human mobility in Italy II: the slave population." 95 Journal of Roman Studies 64-79.

Scheidel, Walter. 2005b. "Real slave prices and the relative cost of slave labor in the Greco-Roman world." 35 Ancient Society 1-17.

Scheidel, Walter. 2008. "Roman population size: the logic of the debate," in Luuk de Ligt and Simon J. Northwood, eds, People, Land, and Politics: Demographic Developments and the Transformation of Roman Italy, 300 $B C-A D$ 14. Leiden: Brill, 17-70.

Scholl, Reinhold. 2001. “'Freilassung unter Freunden’ im römischen Ägypten," in Heinz Bellen and Heinz Heinen, eds, Fünfzig Jahre Forschungen zur antiken Sklaverei an der Mainzer Akademie, 1950-2000. Stuttgart: Steiner, 159-69.

Sirks, A. J. Boudewijn. 1981. "Informal Manumission and the lex Junia." 28 Revue Internationale des Droits de l'Antiquité 247-76.

Sirks, A. J. Boudewijn. 1983. "The lex Iunia and the effects of informal manumission and iteration." 30 Revue Internationale des Droits de l'Antiquité 211-92.

Straus, Jean A. 2004. L'achat et la vente des esclaves dans l'Egypte romaine: contribution papyrologique à l'étude de l'esclavage dans une province orientale de l'Empire romain. Munich: Saur.

Temin, Peter. 2001. "A market economy in the early Roman Empire." 91 Journal of Roman Studies 169-81.

Temin, Peter. 2004. "The labor market of the early Roman Empire." 34 Journal of Interdisciplinary History 513-38.

Treggiari, Susan. 1975a. "Jobs in the household of Livia." 43 Papers of the British School at Rome 48-77.

Treggiari, Susan. 1975b. "Family life among the staff of the Volusii." 105 Transactions of the American Philological Association 393-401.

Verboven, Koenraad. 2012. "The freedman economy of Roman Italy," in Sinclair Bell and Teresa Ramsby, eds, Free at Last! The Impact of Freed Slaves on the Roman Empire. London: Bloomsbury, 88-109.

Wacke, Andreas. 2001. "Manumissio matrimonii causa. Die Freilassung zwecks Heirat nach den Ehegesetzen des Augustus," in Heinz Bellen and Heinz Heinen, eds, Fünfzig Jahre Forschungen zur antiken Sklaverei an der Mainzer Akademie, 1950-2000. Stuttgart: Steiner, 133-57.

Watson, Alan. 1987. Roman Slave Law. Baltimore: Johns Hopkins University Press.

Weaver, Paul R. C. 1972. Familia Caesaris: A Social Study of the Emperor's Freedmen and Slaves. Cambridge: Cambridge University Press.

Weaver, Paul R. C. 1990. "Where have all the Junian Latins gone? Nomenclature and status in the early Empire." 20 Chiron 275-305. 
Weaver, Paul R. C. 1997. "Children of Junian Latins," in Beryl Rawson and Paul R. C. Weaver, eds, The Roman Family in Italy: Status, Sentiment, Space. Oxford University Press: Oxford, 55-72.

Westermann, William L. 1955. The Slave Systems of Greek and Roman Antiquity. Philadelphia: American Philosophical Society.

Wiedemann, Thomas E. J. 1985. "The regularity of manumission at Rome." 35 The Classical Quarterly 162-75.

Zelnick-Abramovitz, Rachel. 2005. Not Wholly Free: The Concept of Manumission and the Status of Manumitted Slaves in the Ancient Greek World (Mnemosyne suppl. 266). Leiden: Brill. 
Comp. by: E.Dharaniraj Stage : Proof ChapterID: 0004665260 Date:9/1/20 Time:09:21:59 Filepath:D:/BgPr/OUP_CAP/IN/Process 1/0004665260.3d

OUP UNCORRECTED PROOF - FIRST PROOF, 9/1/2020, SPi 